\title{
분리된 관심의 척도 타당화 및 직무열의와의 관계 연구*
}

\author{
남 지 선 \\ 박 형 인 \\ 성균관대학교 심리학과
}

\begin{abstract}
본 연구는 고객응대상황에서 정서노동자들이 고객에 가지는 태도와 관련된 분리된 관심이라 는 개념을 한국 표본을 대상으로 적용하고자 하였다. 연구 1 에서는 분리된 관심 척도를 한 국어로 번안한 후 역번역 과정을 거쳐 문항을 가다듬고, 고객응대 업무를 수행하는 만 19세 이상 한국 주간 전일제 근무자 143 명을 대상으로 직무탈진의 세 하위요인을 준거변수로 활 용해 타당도를 확인하였다. 연구 1 의 결과, 분리된 관심의 두 하위요인인 분리와 관심은 독 립적인 차원으로 나타났고, 삼차원적 반응표면그래프를 바탕으로 분리와 관심이 높은 수준 에서 일치할수록 직업비효능감이 감소하는 것을 확인했다. 연구 2 에서는 연구 1 의 척도를 사용하여 한 달 간격으로 두 번의 설문조사를 진행해 374 명의 고객응대근로자에게서 분리된 관심과 한 달 후 직무열의의 세 하위요인 간의 관계를 살펴봤다. 또, 그 관계에서 직무통제 가 조절변수로 작용해 관계를 약화시키는지 알아봤다. 그 결과, 분리와 관심의 수준이 직무 열의에 영향을 미치는 것을 확인했다. 또한, 그 관계에서 직무통제가 조절변수로 작용하였으 나, 직무열의의 각 하위요인들에 따라 직무통제의 조절효과가 다르게 나타났다. 이러한 연구 결과는 분리된 관심이 정서노동자들의 심리적 웰빙에 중요한 영향을 미칠 수 있음을 시사한 다. 연구결과를 바탕으로 학문적 및 실무적 시사점을 제시하고 후속연구 방안을 제안하였다.
\end{abstract}

주요어 : 분리된 관심, 척도 타당화, 직무탈진, 직무열의, 직무통제, 반응표면그래프

* 연구 1 의 자료는 한국산업및조직심리학회 2020 춘계학술대회 포스터연구로 발표되었음. 연구 2의 자료는 정부의 4단계 BK21 사업에서 지원을 받아서 수집되었음.

† 교신저자 : 박형인, (03063) 서울특별시 종로구 성균관로 25-2 성균관대학교 심리학과 교수 Tel: 02-760-0485, E-mail: hi.park@skku.edu 


\section{서 론}

한국의 산업 구조가 서비스업 중심으로 변 화되면서 정서노동자가 증가하게 되었다. 고용 노동부(2017)에 의하면, 정서노동자는 전체 임 금노동자의 약 $31 \sim 41 \%$ 로 추정된다. 정서노동 (emotional labor)은 사회학에서 먼저 등장한 개 념으로, 조직의 요구와 규범에 따라 종업원이 일에서 정서적 표현을 통제하는 행위를 의미 한다(Hochschild, 2012). Hülsheger와 Schewe(2011) 의 메타분석에 따르면, 조직의 표현규칙(display rule)과 종업원 정서 간의 불일치는 종업원의 웰빙과 직무 태도에 부정적인 영향을 미친다. 또한, 고객응대 업무를 수행하는 근로자들이 직무탈진(burnout)이 높다는 것을 보여주는 연구들도 많이 존재한다(Hülsheger \& Schewe, 2011; Kammeyer-Mueller et al., 2013). 현재까지 의 정서노동 연구들은 보통 두 가지 형태의 전략인 표면행위(surface acting)와 내면행위(deep acting)를 구분해 각각의 효과 차이에 초점을 맞췄다(Grandey, 2000; Hochschild, 2012). 반면, 서로 다른 형태의 전략을 구분하기보다 근로 자와 고객 간의 상호작용 상황에서 이상적인 태도를 살펴보는 연구들도 존재한다. 본 연구 는 정서노동 상황에서 종업원이 고객을 대할 때의 태도에 초점을 둔 분리된 관심(detached concern)이라는 개념을 소개하려고 한다. 정서 노동의 두 유형에 더해 고객을 대하는 태도에 있어서의 선택권까지 추가되면 정서노동자의 입장에서는 가용한 대처전략의 폭이 확장될 것이다.

이전까지 분리된 관심은 의학 분야에서 환 자에 대한 의료인의 태도를 설명하는 개념으 로 사용되어 왔다(Lampert \& Glaser, 2018). 이 개념은 분리(detachment)와 관심(concern)의 두
요소로 나뉜다. 분리는 전문적인 대응을 위한 환자와의 감정적 분리를 의미하며, 관심은 자 신의 환자에 대한 공감과 걱정을 보이는 측면 이다(Cadge \& Hammonds, 2012). 이러한 두 요 소는 환자의 상황과 감정에 공감적 이해를 보 이는 동시에 의료진의 전문성 유지에 도움이 되기 때문에(Coulehan, 2012), 분리와 관심의 적 절한 균형은 효과적인 환자 응대를 위해 필수 적이다. Lampert와 Glaser(2018)는 환자에 대한 분리된 관심 척도를 일반 고객응대 상황으로 확장시켜 산업 및 조직심리 분야에 적용했는 데, 이 연구는 고객에 대한 높은 분리와 높은 관심의 균형이 정서노동자의 직무탈진을 낮추 는 효과가 있음을 확인했다(Lampert \& Glaser, 2018). 본 연구는 측정도구에 초점을 맞춘 연 구 1 과 새로운 가설을 검정하는 연구 2 로 나 뉜다. 연구 1 에서는 분리된 관심을 측정하기 위한 해외 도구를 번안하고 기존에 확인된 결 과변수인 직무탈진을 활용하여 한국어 버전의 준거타당도(criterion validity)를 확인할 것이다. 연구 1 은 직장인 143 명을 대상으로 일회 설 문조사를 바탕으로 한 자료를 분석하였다. 연 구 2에서는 타당화한 한국판 분리된 관심 척 도를 사용하여 분리된 관심과 직무열의(work engagement)의 관계를 알아보고, 그 관계에서의 조절변수를 조사하고자 한다. 연구 2에서는 한 달 간격으로 두 번 설문조사를 실시하여 두 번의 설문에 모두 참여한 374 명의 자료를 분석에 사용하였다.

본 연구는 다음과 같이 관련 학계에 공헌할 수 있다. 첫째, 본 연구는 분리된 관심의 개념 을 국내 최초로 한국 직장인 표본에 적용하고 한국판 분리된 관심 척도의 타당도를 확인함 으로써 서비스 종사자 연구를 촉진할 것으로 기대한다. 둘째, 기존에 적용되지 않은 직무열 
의를 결과변수로 사용함으로써 긍정적 직무 태도와의 관계를 살펴볼 것이다. Lampert와 Glaser(2018)의 연구에서는 직무탈진만을 결과 변수로 사용하였기에 직무열의와의 관계 확인 은 적용범위를 확장시킬 수 있다. 또, 한 달 간격의 종단설계를 통해 분리와 관심의 수준 이 직무열의에 미치는 영향을 확인하여, 횡단 설계를 적용했을 때에 비해 역인과의 가능성 을 차단하고 인과관계를 조금 더 엄격하게 확 인할 수 있다. 셋째, 직무자원이 직무요구와 종업원 웰빙의 관계에서 완충작용을 한다는 직무자원-요구 이론(Job demands-resources theory) 에 따라 분리된 관심과 직무열의의 관계 사이 를 조절하는 변수로 직무통제(job control)를 제 시한다. 분리와 관심이 적절한 균형을 이루지 못하면 부정적 결과가 나타날 수 있는 반면 (Lampert \& Glaser, 2018), 이를 완충해 줄 수 있는 요인이 있다면 정서노동자의 웰빙을 도 모하는 데 활용할 수 있을 것으로 기대한다. 종합적으로, 기존의 서비스 종사자 연구가 정 서노동의 유형 및 그 결과에 초점을 맞춘 데 비해(e.g., Park, 2019), 본 연구는 고객을 대하 는 바람직한 태도로서의 분리된 관심을 제안 하여 정서노동의 부정적 효과에 대한 대처방 안을 마련하고자 한다.

\section{연구 1}

\section{분리된 관심의 개념 및 요인구조}

분리된 관심은 환자와의 정서적 분리와 환자에 대한 걱정 사이의 동적 균형(dynamic balance)이다(Halpern, 2001). 즉, 분리된 관심은 고객을 너무 가까이 하지 않으면서 고객에게
관심을 가지는 것이다(Dickinson et al., 1997). Lampert와 Glaser(2018)는 분리된 관심을 정서적 반응(관심)과 이에 대응하기 위한 정서조절전 략(분리)의 조합으로 정의하였다. 즉, 분리된 관심은 두 개의 비교적 독립적인 차원인 분리 와 관심으로 구성된 이중 요인 개념이다.

이 중 관심의 정의는 $\operatorname{Davis(1983)ㅇㅢ~ㅇㅕㄴㄱㅜㅇㅔ~}$ 서 차용되었다(Lampert, 2011; Lampert et al., 2019) Davis(1983)는 관심을 타인 지향적인 공 감(other-oriented sympathy)으로 정의했다. 관심 은 고객의 요구와 감정을 인식하는 결과로 발 생하는 정서로(Halpern, 2001), 종업원과 고객 간의 공감대를 형성하고 고객 만족을 형성 하는 데 도움이 된다는 점에서 원활한 고객 상호작용의 중요한 요소이다(Wieseke et al., 2012). 또, 고객응대에서 공감적 관심을 표현 하는 것은 고객의 긴장 상태를 완화시킬 수도 있다(Wieseke et al., 2012). 이처럼 적절한 관심 은 바람직하지만, 관심이 높은 강도로 지속될 경우 동정 피로(compassion fatigue)로 이어질 수 있다. 이는 연민과 공감의 행위가 지속될 경 우 발생하는 특수한 피로이다(Figley, 2002). Figley(2002)의 동정 피로 모델에 따르면, 분리 는 공감적 관심으로 인한 스트레인을 낮추거 나 동정 피로를 예방할 수 있다. 따라서 고객 상호 작용에는 관심이 필요하지만 과도할 경 우 종업원의 정신 건강에 해로울 수 있으며, 대처하기 위해 정서조절전략인 분리와 적절히 균형을 이루어야 한다.

스트레스와 대처(coping) 연구의 맥락에서는 보통 정서조절전략을 부정적인 감정을 줄이기 위한 의식적이고 목표지향적인 시도로 인식한 다(Gross, 2015). 따라서 분리는 정서노동에서 발생하는 부정적 영향에 대한 보호 장치이자 대응으로, 고객으로부터 정서적인 거리를 유 
지하는 것이다(Lampert \& Glaser, 2018). 의료진 들은 환자와의 분리를 통해 객관성을 유지하 는 것이 중요하고, 이는 궁극적으로 치료의 질을 향상시키기 위해 필요하다(Jensen, 1994). 환자에 대한 공감에서 생기는 정서를 효과적 으로 다뤄야만 전문적인 대응에 필요한 객관 적 상태를 유지하고 정서적 반응으로 인한 오 류를 줄일 수 있기 때문이다(Halpern, 2001). 분 리는 정서노동을 하는 종업원들이 고객을 대 할 때에도 필요할 수 있는데, 고객 상호작용 과정은 고객의 입장과 감정에 공감하면서도 정서적 분리를 통해 일정 수준의 전문성을 유지해야 신뢰를 얻을 수 있기 때문이다 (Hochschild, 2012). 분리의 실패로 고객의 감정 에 동화되거나 압도될 경우, 성공적인 고객응 대업무 수행을 위한 전문성을 유지하기 어려 울 수 있다. 또한, 분리는 정서조절전략으로 공감적 관심의 바람직하지 않은 영향을 줄이 는 것을 목표로 한다(Figley, 2002). 고객을 상 대하는 직원들이 정서적으로 고객과 동일시하 게 되면, 고객의 요구에 부응하지 못할 경우 역할 갈등, 스트레스 등 다양한 부정적인 반 응으로 이어진다(Varca, 2007). 따라서 고객과 자신은 각자 다른 정서적 주체이며, 고객응대 는 업무의 일환이라는 인지적 분리가 가능해 야 안정적으로 업무를 수행할 수 있다. 한편, 분리된 관심에서의 분리는 널리 사용되는 심 리적 분리(psychological detachment)라는 용어와 구별해야 한다. 심리적 분리는 직장을 떠난 시간 동안 일과 관련된 생각 및 활동 등에 관 여하지 않는 것이다(Sonnentag \& Bayer, 2005). Lampert와 Glaser(2018)는 심리적 분리가 일 외 시간(nonwork time)과 관련된 개념이라면, 분리 된 관심에서의 분리는 일에서 고객과 상호작 용할 때 생기는 정서적 불편감으로부터 자신
을 보호하기 위한 기작이라는 점에서 두 개 념이 다르다고 주장한다. 하지만 보호기작으 로서의 분리가 너무 높아질 경우 비인격화 (depersonalization) 및 둔감화(desensitization)를 초 래할 수 있으며, 이로 인해 적절한 고객응대 에 방해가 될 수 있다(Druce \& Johnson, 1994; Gustavson, 1988; Lampert et al., 2019). 따라서 종업원과 고객에게 부정적인 결과를 초래하지 않기 위해 분리는 공감적 관심을 동반해야 한 다.

일부 연구들은 분리를 통해 고객에 대한 관 심의 수준을 제어한다고 주장하는데, 이들은 관심보다 분리에 초점을 맞추며, 분리를 관 심과 정반대인 개념으로 설명한다(Coombs \& Goldman, 1973; Mannon, 1981). 하지만 Cadge와 Hammonds(2012)는 이러한 연구들이 분리와 관 심의 공존을 주장하는 분리된 관심의 원래 개 념과 다르다고 주장한다. 즉, 분리된 관심에서 분리와 관심은 동일선상의 양 극단에 있는 개 념들이 아니다. 분리는 고객을 대면하는 상황 에서 객관성을 유지하고, 정서적 반응에 압도 되는 것을 방지하여 대응의 질을 높일 수 있 게 하는 요소이다(Jensen, 1994). 관심은 고객에 대한 공감과 고객을 진정으로 위하는 마음으 로(Hojat et al., 2002), 분리의 실패와 다르다. 따라서 분리와 관심은 아예 다른 차원의 개념 으로 공존이 가능하며, 적절한 수준의 균형이 중요하다.

가설 1. 분리와 관심의 두 가지 개념은 서 로 독립적인 요인구조를 보일 것이다.

\section{분리된 관심의 준거변수로서 직무탈진}

분리와 관심의 적절한 균형이 중요하다는 
의미는, 분리와 관심 중 어느 하나가 다른 하 나보다 더 높거나 낮은 불균형의 상태일 때는 직무탈진과 같은 결과가 악화된다는 것이다. 직무탈진은 직장에서의 만성적인 대인관계적 스트레스원에 대한 심리적 증후군으로 처음 개념화되었으며, 소진, 냉소, 직업비효능감의 세 가지 요소로 측정된다(Maslach et al., 2001). 소진은 신체적, 정서적 자원의 고갈이며, 냉소 는 일의 여러 측면에 냉담하고 부정적인 태도 를 뜻한다. 직업비효능감은 직무탈진의 요소 중 자신의 수행에 대한 평가이며, 일에서 생 산성과 성취감이 부족할 때를 말한다(Maslach et al., 2001).

Lampert와 Glaser(2018)는 Elfenbein(2007)이나 Gross(1998) 등의 영향을 받아 정서조절(emotional regulation)의 일환으로 분리와 관심의 효과에 대해 설명하였다. 고객과의 상호작용은 자극 의 역할을 하여 고객응대 업무자에게 정서적 반응을 불러일으킨다. 자극에서 반응으로 이 어지는 과정 속에서 근로자는 정서를 인식하 고, 경험하며, 표현하는데(Elfenbein, 2007), 이 때 근로자가 보이는 분리와 관심의 수준에 따 라서 표현적 단서가 달라지며, 그에 따라 효 과 또한 차이가 난다(Lampert \& Glaser, 2018).

성공적인 정서조절전략인 분리와 관심의 균 형은 직무탈진을 감소시킨다(Lampert \& Glaser, 2018). 분리와 관심이 동일한 수준일 때는 직 무탈진이 낮아지고, 균형이 깨져 불일치가 커 질수록 직무탈진이 높아질 수 있다. 경험적으 로도, 분리와 관심이 일치하지 않을 때 높은 관심과 낮은 분리는 정서적 소진(emotional exhaustion)으로 이어진다는 연구 결과가 존재 하며, 불일치의 정도가 커질수록 정서적 소진 이 증가하였다(Lampert \& Glaser, 2018). 이 경 우, 높은 관심 수준을 뒷받침할 수 있는 정서
조절전략이 불충분하기 때문에 정서노동자 들은 동정 피로에 취약해질 수 있다(Figley, 2002). 반면에 분리가 관심보다 높아질 경우 그 차이가 커질수록 비인격화(depersonalization) 가 증가하였다(Lampert \& Glaser, 2018; Lampert et al., 2019). 비인격화는 서비스 수혜자에 대 한 냉담한 반응으로, 냉소와 비슷한 개념이다 (Maslach et al., 2001). 종업원들이 고객과 상호 작용을 할 때 어떤 정서적 반응이 일어나기 전부터 고객과 정서적으로 거리를 둘 경우, 고객을 대하는 태도가 냉소적일 수 있다. 이 와 같은 이전 연구들에 따라 분리된 관심의 준거타당도를 확인하기 위해 직무탈진을 준거 변수로 활용해 다음과 같이 가설을 설정했다.

가설 2. 분리와 관심의 수준이 일치할수록 직무탈진(a. 소진, b. 냉소, c. 직업비효능감)이 감소하고, 불일치할수록 직무탈진이 증가할 것이다.

또한, 분리와 관심이 균형의 상태라고 해도 두 차원의 구체적인 수준에 따라서 직무탈진 수준이 달라질 수 있다. 다시 말해, 낮은 분리 -낮은 관심보다 높은 분리-높은 관심이 더 긍 정적인 효과로 이어질 가능성이 존재한다. 관 련된 두 개념의 일치나 불일치에 따른 결과를 조사한 최근의 연구들은 일치할 경우에도 저저 일치보다 고-고 일치가 더 효과적일 수 있다고 주장한다(Goswami et al., 2020; KristofBrown \& Stevens, 2001). 고객에게 공감적 관심 을 표현하는 것은 고객응대의 질에 긍정적 영 향을 미치기 때문에(Wieseke et al., 2012), 낮은 관심은 성공적 고객응대 업무 수행의 실패와 관련될 수 있다. 이와 동시에 전문성 유지를 위한 분리 또한 낮을 경우, 업무를 제대로 수 
행하지 못하고 있다는 생각으로 인해 직업비 효능감 등이 증가할 것이다. 반대로 분리와 관심이 모두 높을 경우, 고객과의 상호작용이 원활하게 이루어지는 동시에 높은 관심으로 인한 소진 등의 부정적 영향을 높은 분리를 통해 줄일 수 있다. 실제로, 높은 분리와 높은 관심이 공존할 경우 종업원의 직무탈진이 낮 아진다는 연구들이 존재한다(Lampert \& Glaser, 2018; Lampert et al., 2019).

가설 3. 분리와 관심이 낮은 수준보다 높은 수준에서 일치할수록 직무탈진(a. 소진, b. 냉 소, c. 직업비효능감)이 감소할 것이다.

방법

\section{연구대상 및 절차}

연구 1 의 대상은 정신건강 연구에 참여한 만 19세 이상 한국 주간 전일제 근무자 중 고 객응대 업무를 수행한다고 응답한 참가자들로 설정했다. 대학 소속 생명윤리심의위원회의 승인을 득한 후, 2020년 2월에 온라인 설문조 사회사의 패널을 통해 일회의 자기보고식 온 라인 설문조사를 실시하였다. 사전질문을 통 해 조건에 부합하는 사람들에게만 연구에 대 한 설명서를 제공하였고, 동의를 클릭한 사람 에 한하여 본 설문에 참여할 수 있게 한 결과, 총 333 명이 전체 연구에 응답하였다. 이 중 고객응대 업무를 한다고 답한 143 명에게만 분 리된 관심과 직무탈진 척도들을 제시하여 연 구 1 의 최종 표본으로 사용하였다.

본 조사에 참여한 사람들은 남성이 81 명 (56.6\%), 여성이 62명(43.4\%)이었으며 평균 연 령은 45.4세였다 $(S D=11.8)$. 이 중 기혼이 100 명(69.9\%)으로, 18 세 미만의 자녀가 있는 기혼
자들이 51 명(51.0\%)이었다. 거주 지역은 경기 도가 46명(32.2\%)으로 가장 많았고, 서울 44명 (30.8\%), 인천 9명(6.3\%) 등으로 나타났다. 직 업은 관리/지원(45.5\%), 영업(14.0\%), 보건/의 료(12.6\%), 기술(9.1\%), 공무(4.2\%), 연구/개발 (4.2\%), 생산(2.1\%), 그리고 기타(교육, 서비스, 사회복지 등; $8.4 \%)$ 로 다양했다.

\section{측정도구}

직무탈진. 직무탈진을 측정하기 위해 Shin (2003)의 한국형 직무탈진 척도를 사용하였다. 직무탈진은 소진(exhaustion), 냉소(cynicism), 직 업비효능감(professional inefficacy)의 세 가지 하 위요인으로 구성되어 있으며, 7점 척도로 측 정하였다 $(1=$ 전혀 아니다, $7=$ 매우 그렇다). 척도는 총 15 문항으로, 이 중 소진 다섯 문항 ("내가 맡은 일을 하는 데 있어서 정서적으로 지쳐있음을 느낀다”), 냉소 네 문항(“나의 직무 의 기여도에 대해서 더욱 냉소적으로 되었 다”), 그리고 직업비효능감 여섯 문항(“내가 생 각할 때, 나는 일을 잘한다")으로 구성된다. 직 업비효능감의 문항은 모두 역코딩을 하여 세 하위요인 모두 점수가 높을수록 직무탈진이 높다는 것을 의미한다. 하위요인의 신뢰도는 내적일치도(internal consistency)로 측정하였으며, 소진, 냉소, 그리고 직업비효능감의 신뢰도는 소수점 둘째자리까지 반올림했을 때 각각 .91 로 동일하게 나타났다.

분리된 관심. 척도를 번역하기 앞서, 원래 척도의 개발자들에게 연락하여 한국어 번역 및 타당화 연구에 대한 승인을 구하였다. 이 메일로 사용허가를 받은 후, 제 1 저자가 영어 로 작성된 전체 11 문항을 한글로 번역하였다. 그 후 원 척도를 보지 않은 제 2 저자가 한글번 
역본을 다시 영어로 역번역을 하였다. 영어와 한국어에 능통한 산업 및 조직심리학 석사학 위 소지자 한 명에게 원 문항과 역번역 문항 의 내용일치도 평가를 요청한 결과, 총 5.00점 만점 중 평균 4.55 의 일치도 점수를 보였다. 문항의 내용일치도는 간단한 척도를 만들어서 각 11 개 문항의 쌍이 서로 얼마나 유사하거나 다른지 $(1=$ 매우 상이, $5=$ 매우 유사)를 평 가하도록 하였다. 평가 의견에 기반하여 한 문항의 표현을 추가로 수정하여 자료수집을 실시하였다.

수집된 자료로 내적일치도 검사, 문항 간 상관분석, 그리고 확인적 요인분석을 실시하 였고, 분석결과를 바탕으로 총 다섯 문항을 삭제하여 각 하위요인이 세 문항으로 구성되 도록 최종 척도를 구성하였다. 삭제된 문항들 은 요인부하량이 가장 낮으면서 삭제했을 때 내적일치도를 향상시키는 항목들이었다. 분리 하위요인에서는 "나의 고객들은 내게 심적으 로 매우 가깝지만, 나는 내가 고통 받지 않는 정도까지만 고객들과 관여한다" 등이 포함되 었고, 관심 하위요인에서는 "나는 일에서 고객 들의 걱정과 두려움에 대해 그들과 이야기한 다" 등이 삭제되었다.

최종 척도에는 "나는 일에서 나의 고객들과 관계를 맺지만, 스스로에게 정서적인 부담감 을 주지 않는다" 등(분리)과 “고객들과 일을 할 때, 나는 그들을 반복적으로 안심시킨다" 등(관심)이 포함되었다. 각 문항은 5점 척도로 측정되었으며 $(1=$ 매우 그렇지 않다, $5=$ 매 우 그렇다), 신뢰도는 분리 .80 , 관심 .85 로 나 타났다.

통제변수. 국내외 많은 연구들이 업무량이 본 연구의 결과변수인 직무탈진에 영향을 미
칠 수 있음을 증명하였다(e.g., Dorman, 2003; Kim \& Park, 2014; Peiró et al., 2001). 이에 업무량을 측정하여 통제하기 위해 역할과부 하(role overload)를 활용했다. 역할과부하는 $\operatorname{Kim}(2015)$ 의 역할 스트레스원 척도 중 역할과 부하 하위척도를 사용했고, 문항의 예시로 "나 는 한 사람이 수행하기에 너무 많은 일을 한 다" 등이 있다. 문항은 5점 척도로 측정했고(1 = 매우 그렇지 않다, 5 = 매우 그렇다), 신뢰 도는 .91로 나타났다. 역할과부하와 준거변수 인 직무탈진 세 하위요인과의 상관을 분석한 후, Becker 등(2016)의 권고에 따라 유의한 상 관이 나타 난 하위요인에서만 역할과부하를 통제하였다(표 1). 즉, 역할과부하가 소진과 유 의한 관계를 보였고, $r=.63, p<.001$, 냉소 와도 관계가 유의했기 때문에, $r=.51, p<$ .001 , 소진과 냉소의 다항회귀분석에서만 첫 단계에서 역할과부하를 통제했다.

\section{자료분석}

가설 1 을 검정하기 위해 LISREL 9.30 프로 그램(Jöreskog \& Sörbom, 2017)으로 확인적 요 인분석을 시행하였다. 기존에 이론적으로 정 립된 요인구조를 중심으로 가설을 설정하고 검정하기 때문에 탐색적 요인분석은 생략하고 확인적 요인분석만을 시행하였다. 척도를 처 음 개발하는 경우에도 명확한 이론을 바탕으 로 각 문항들이 특정 요인을 대표하도록 작성 되었다면 탐색적 요인분석 대신 확인적 요인 분석이 사용될 수 있다(DeVellis, 1991). 확인적 요인분석은 한 척도를 구성하는 총 요인의 숫 자만이 아니라 각 문항이 이론적으로 의도했 던 요인의 관찰변수로 묶이는지도 미리 지정 하여 경험적 자료와 선험적 모형 간 일치를 
검사한다(DeVellis, 1991). 해외 척도를 한국어 로 번역하여 타당도를 조사한 선행연구들(Park et al., 2011; Shin, 2003)도 탐색적 요인분석 대 신에 확인적 요인분석만을 활용하는 사례를 보여 주었다. 나아가 네 가지 문화권을 대표 하는 20 개국에서 서로 다른 언어를 통해 수집 한 자료를 분석하여, 같은 척도의 경우 문화권 이 달라도 측정모형의 동일성(scale equivalence) 이 확인된다는 결과도 존재한다(Spector et al., 2007). 이런 증거들을 바탕으로 바로 확인적 요인분석을 적용하였으며, 최종적으로 선정된 총 여섯 개의 문항들을 대상으로 두 개의 요 인구조를 비교하여, 두 개의 잠재요인으로 구 성된 모형(연구모형)이 한 개의 잠재요인으로 구성된 모형(대안모형)보다 더 좋은 적합도를 보이는지 알아보았다. 각 잠재변수에는 이론 적으로 그 요인을 지시한다고 가정된 세 개씩 의 문항들을 관찰변수로 지정하였다.

다음으로, 분리된 관심과 직무탈진의 관계를 검정하기 위해 다항회귀(polynomial regression)분 석을 실시하였다. 첫째, 두 예측변인인 분리와 관심을 중간점(midpoint; 본 자료에서 3.00)을 이용해 중심화(centering)하였다(Shanock et al., 2010; 2014). 둘째, 중심화된 변수들을 이용해 고차항을 계산했다(분리 ${ }^{2}$, 관심 ${ }^{2}$, 분리 $\times$ 관심). 셋째, 저차항과 고차항을 포함한 총 다섯 가 지 항을 이용하여 직무탈진의 각 하위요인에 대해 회귀분석을 따로 실시한 후, 세 회귀분 석의 전체 모형이 유의한지 확인하였다. 전술 한 것과 같이, 소진과 냉소의 경우 역할과부 하를 먼저 통제하였고, 역할과부하의 설명력 은 각각 소진에서 .40, 냉소에서 .26으로 나타 났다. 소진과 냉소 모두에서 통제변수의 유무 가 다항회귀 전체 모형의 유의도에 크게 영향 을 주지 않았다. 이에 따라 간결성을 위해 통
제변수를 제외한 결과를 보고하였다.

전체 모형이 유의할 경우, 반응표면그래프 (response surface graph)를 그려 관계를 삼차원적 으로 살펴보았다. 또한 그래프를 해석하는 데 도움을 주는 참조선인 일치선(분리 $=$ 관심)과 불일치선(분리 $=$-관심)의 기울기(slope)와 곡률 (curvature)을 각각 확인했다. 가설 2가 지지되 기 위해서는 불일치선의 기울기가 유의하지 않고, 곡률이 유의해야 한다. 또, 가설 3이 지 지되기 위해서는 일치선의 기울기가 부적으로 유의하고, 곡률이 유의하지 않아야 한다.

\section{결과}

표 1 에 본 연구에서 사용한 변수들의 평균, 표준편차, 내적일치도 및 각 변수 간 상관계 수를 제시하였다. 분리와 관심 각각은 소진이 나 냉소와는 유의한 상관을 보이지 않았으나, 직업비효능감과는 유의한 상관을 보였다. 분 리와, $r=-.48, p<.001$, 관심이 클수록, $r=$ $-.32, p<.001$, 직업비효능감이 감소하였다.

분리와 관심이라는 두 개념이 상관을 갖지 만 독립된 두 잠재요인으로 구성된 모형의 적 합도는 수용할 만 한 결과를 보였다, $X^{2}(8)=$ 51.23, $p<.001$, CFI $=.92$, RMSEA $=.19$, $\mathrm{SRMR}=.05$. 모든 문항이 하나의 잠재요인으 로 수렴하는 모형의 경우, 이보다 훨씬 나쁜 적합도를 보였다, $\mathrm{X}^{2}(9)=229.89, p<.001$, $\mathrm{CFI}=.58, \mathrm{RMSEA}=.41, \mathrm{SRMR}=.23$. 두 모 형 간 차이는 통계적으로 유의해서 한 개의 잠재요인보다 두 개의 잠재요인 모형이 더 우 수하게 나타났다, $\Delta \mathrm{x}^{2}(1)=178.66, p<.001$. 따라서 가설 1 이 지지되었고, 표 2에 최종 선 택된 모형에서 각 문항의 요인부하량을 제시 했다. 
남지선·박형인 / 분리된 관심의 척도 타당화 및 직무열의와의 관계 연구

Table 1. Descriptive Statistics and Correlations between Study 1 Variables

\begin{tabular}{|c|c|c|c|c|c|c|c|c|}
\hline Variable & $M$ & $S D$ & $a$ & 1 & 2 & 3 & 4 & 5 \\
\hline 1. Role Overload & 2.84 & 0.86 & .91 & & & & & \\
\hline 2. Detachment & 3.58 & 0.71 & .80 & .02 & & & & \\
\hline 3. Concern & 3.51 & 0.72 & .85 & .00 & $.17^{*}$ & & & \\
\hline 4. Exhaustion & 4.31 & 1.19 & .91 & $.63^{* * * *}$ & .09 & -.01 & & \\
\hline 5. Cynicism & 3.55 & 1.18 & .91 & $.51^{* * *}$ & -.06 & -.12 & $-.66^{* * *}$ & \\
\hline 6. Professional Inefficacy & 3.04 & 0.91 & .91 & -.00 & $-.48^{* * *}$ & $-.32^{* * *}$ & -.04 & $.18^{*}$ \\
\hline
\end{tabular}

Table 2. Factor Loadings of Items from the Final Confirmatory Factor Analysis

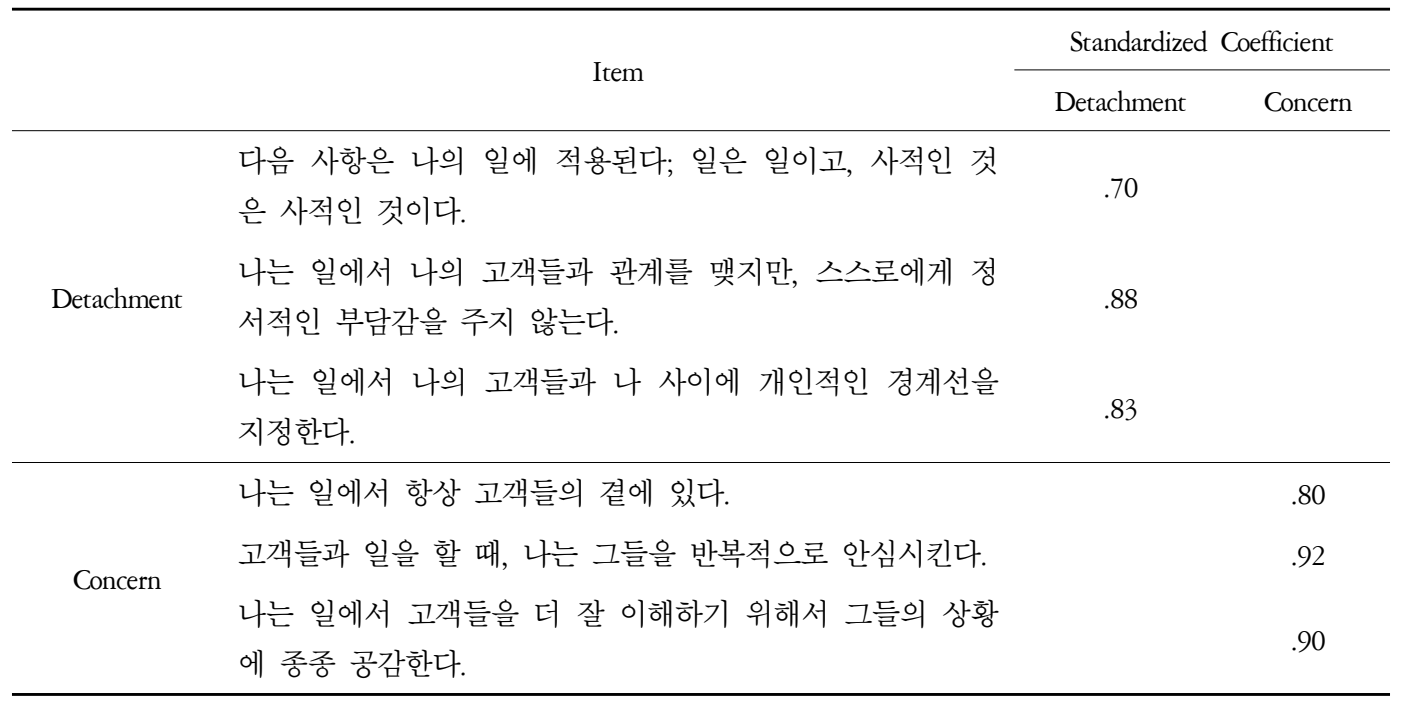

Note. $N_{1}=143$.

표 3에 분리-관심 부합과 직무탈진의 관계 를 제시했다. 상관은 유의하지 않더라도 고차 항으로 확인되는 비선형 관계는 존재할 수 있 으므로 세 결과변수 모두에서 다항회귀를 실 시하였다. 다항회귀분석 결과, 분리와 관심은 역할과부하의 통제 유무와 관계없이 소진을 유의하게 설명하지 않았고, $\Delta R^{2}=.04, \Delta F=$
$1.70, n s$, 냉소 또한 유의하게 설명하지 않았다, $\Delta R^{2}=.02, \Delta F=0.90, n s$. 따라서 가설 2-a와 2-b, 3-a와 3-b는 지지되지 않았다. 그렇지만, 직무탈진의 직업비효능감 차원에서는 전체 회 귀모형이 유의했고, $R^{2}=.32, F=12.77, p<$ .001 , 따라서 반응표면그래프를 통해 관계 양 상을 살펴보았다. 
한국심리학회지: 산업 및 조직

Table 3. Detached Concern on Burnout

\begin{tabular}{|c|c|c|c|c|c|c|c|c|c|c|}
\hline \multirow{2}{*}{ Dependent Variable } & \multicolumn{5}{|c|}{$B$} & \multirow{2}{*}{$R^{2}$} & \multicolumn{2}{|c|}{$\mathrm{D}=\mathrm{C}$} & \multicolumn{2}{|c|}{$\mathrm{D}=-\mathrm{C}$} \\
\hline & $\mathrm{D}$ & $\mathrm{C}$ & $\mathrm{D}^{2}$ & $\mathrm{C} \times \mathrm{D}$ & $C^{2}$ & & Slope & Curvature & Slope & Curvature \\
\hline Exhaustion & .08 & $-.49^{*}$ & -.10 & .21 & $.36^{* *}$ & .06 & - & - & - & - \\
\hline Cynicism & -.17 & -.44 & -.01 & .14 & .18 & .03 & - & - & - & - \\
\hline Professional Inefficacy & $-.45^{* *}$ & $-.34^{*}$ & -.09 & .12 & -.13 & $.32^{* * *}$ & $-.79^{* * *}$ & -.10 & -.12 & -.34 \\
\hline
\end{tabular}

Note. $N_{1}=143 ;{ }^{*} p<.05,{ }^{* *} p<.01,{ }^{* * *} p<.001 ; B=$ unstandardized coefficient; $\mathrm{C}=$ concern, $\mathrm{D}=$ detachment.

반응표면그래프의 해석을 위한 불일치선의 기울기는 유의하지 않았으나, $b=-0.12, n s$, 불 일치선의 곡률은 한계적 유의수준에서 유의했 다, $b=-0.34, p<.10$. 그림 1 을 보면, 분리와 관심이 동일하게 2.00 일 때는 직업비효능감이 1.63 으로 가장 낮은 점수를 보인 반면, 가운데 에서 왼쪽으로 옮겨가면서 분리가 -2.00 에 가까워지면 직업비효능감이 높아졌다(2.48). 비슷하게, 가운데에서 오른쪽으로 옮겨가면서 관심이 -2.00 에 가까워지면 역시 직업비효능 감이 높아졌다(2.02). 다만, 그림 1 의 하단에서 는 이런 양상이 명확하게 관찰된 반면, 상단 에서는 이런 양상이 거의 나타나지 않았다. 따라서 가설 2-c는 예상한 것과 비슷한 양상이 관찰되기는 했으나 궁극적으로 지지되지 않았
다. 반면, 일치선의 기울기가 부적으로 유의했 고, $b=-0.79, p<.001$, 일치선의 곡률은 유 의하지 않았다, $b=-0.10, n s$. 그림 1 을 보면, 분리와 관심이 높은 수준에서 일치할수록 직 업비효능감이 낮고, 낮은 수준에서 일치할 경 우 직업비효능감이 높아지는 선형적 관계가 나타났다. 따라서 가설 3-c는 지지되었다.

\section{논의}

연구 1은 Lampert와 Glaser(2018)의 연구를 토대로 분리된 관심의 요인구조를 조사하는 한편, 직무탈진에 적용하여 준거타당도를 확 인하였다. 연구 결과, 분리된 관심은 분리와 관심의 두 가지 독립적 요인구조를 가진 개념

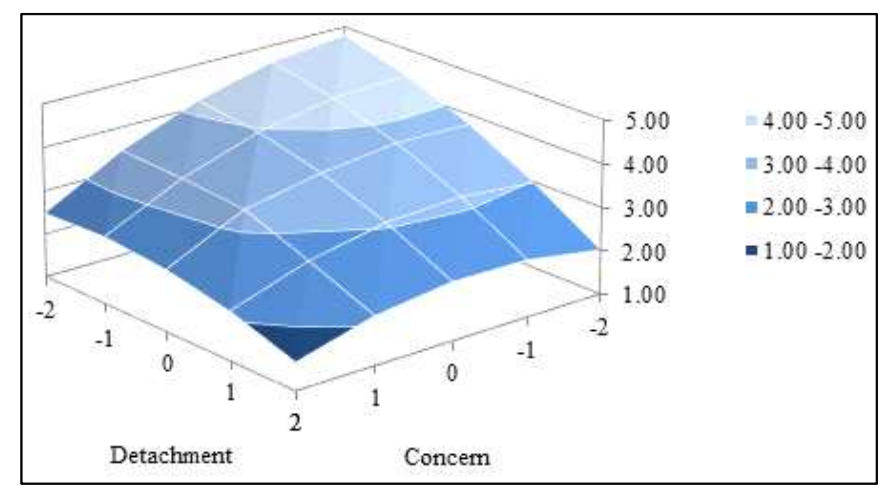

Figure 1. Detached concern on professional inefficacy 
임을 확인했다. 이는 분리와 관심이 각기 다 른 수준을 보이는 것도 가능하고, 동시에 똑 같이 높은 수준을 보이는 것도 가능함을 뜻한 다. 본 자료에서는 분리와 관심이 직무탈진의 다른 두 하위요인과는 별다른 관계를 보이지 않았으나, 직업비효능감을 설명하는 데 있어 서는 유용하게 작용하였다. 특히, 분리와 관심 이 높은 수준에서 일치하는 것이 직업비효능 감을 낮추는 데 효과적이었다. 이는 분리와 관심이 균형을 이루는 것뿐만 아니라 같은 균 형 상태라도 낮은 분리-낮은 관심의 조합보다 높은 분리-높은 관심의 조합이 행위자에게 더 바람직한 정신건강 결과로 이어진다는 것을 뜻한다. 특히, 직업비효능감은 개인의 수행에 대한 자기평가이기 때문에(Maslach et al., 2001), 생산성을 중요시하는 조직의 입장에서는 직무 탈진의 다른 두 하위요인보다 더 관심의 대상 이 될 수 있다. 고객을 위하는 마음인 관심이 높은 동시에 이에 대한 보호로서의 분리가 함 께 높을 경우, 고객응대업무를 성공적으로 수 행해내고 있다는 주관적 평가가 높아질 수 있 다.

Lampert와 Glaser(2018)의 연구는 직무탈진으 로 정서적 소진과 비인격화만을 측정했기 때 문에 직업비효능감에 대한 결과를 직접 비교 하는 것은 불가능하다. 본 연구에서는 Lampert 와 Glaser(2018)의 결과와는 다르게 분리된 관 심이 소진이나 냉소를 유의하게 설명하지 않 았는데, 이는 두 가지 가능성을 고려해 볼 수 있다. 첫째, 표본이 충분히 크지 않았을 수 있 다. Lampert와 Glaser(2018)의 연구에서는 934명 의 표본을 대상으로 다항회귀 및 반응표면그 래프를 적용하였다. 다항회귀는 여러 개의 고 차항이 동시에 모형에 투입되기 때문에 충분 한 표본크기가 확보되어야 한다. 따라서 소진
이나 냉소에서 가설이 지지되지 않은 데에는 표본이 충분히 크지 않아 검정력(power)이 약 했기 때문일 가능성이 있다. 특히, 인구통계학 적 정보들을 통제한 Lampert와 Glaser(2018)의 연구와 다르게 본 연구에서는 역할과부하를 통제하였고, 역할과부하와 소진 및 냉소가 갖 는 관계가 매우 커서 각각 $39.7 \%$ 와 $26.0 \%$ 의 설명력을 보였다. 이에 따라 통제변수의 차이 도 고려해 볼 수 있다. 그렇지만 본 연구에서 는 통제변수의 유무에 따른 다항회귀 결과에 변화가 별로 변화가 없었고 분리와 관심이 소 진이나 냉소와 갖는 단순 상관도 유의하지 않 았기 때문에, 이러한 차이를 다항회귀의 사용 에 따른 검정력의 문제로만 설명하기도 어렵 다. 대안적 설명으로, 이는 표본의 특성이 반 영된 결과일 수도 있다. 정서적 소진 등 직무 탈진의 다른 하위요인만 조사하여 유의하게 설명한 Lampert와 Glaser(2018)의 연구는 독일과 오스트리아 표본을 사용한 반면, 본 연구는 한국인 표본을 통해 가설을 검정했다. 따라서 다른 국가 간 문화적 차이로 인해 결과가 다 르게 나타났을 가능성이 존재한다. 예를 들어, 원래는 분리와 관심이 모두 낮은 수준에서 균 형을 이루고 있던 정서노동자가 조직을 위해 고객에 대한 관심 수준을 높여 분리와 관심의 불일치를 경험할 수 있다. 이런 불일치가 일 어난다고 해도 그로 인한 부정적 결과가 개인 주의적 사회의 구성원보다 집단주의적 사회의 구성원에게서는 훨씬 약할 수 있다. 실제로 한 연구에서는 집단주의적 문화의 영향을 받 는 중국계 미국인들과 개인주의적 문화권인 유럽계 미국인들이 대인적 긴장 상황에서 다 른 대응 방식을 보였고, 이로 인한 정서적 결 과 역시 서로 다르게 나타났다(Luong et al., 2020). 또, 정서노동 상황에서 표면행위와 소 
진 및 냉소의 관계가 미국인들보다 중국인들 에게서 약하게 나타났는데, 이는 집단주의적 문화권의 특성상 고객을 대할 때 실제 감정을 숨기고 조직이 요구하는 감정을 표면적으로 나타내는 것이 꼭 직무탈진으로 이어지지 않 을 가능성이 있다는 점을 시사한다(Allen et al., 2014). 집단주의 성향은 개인의 표현보다 집단을 위한 사회적 조화를 중시하기 때문에 (Hofstede, 2011), 집단주의 문화권의 정서노동 자들은 소속된 집단을 위해 개인의 사적인 감 정을 수정하는 것이 개인주의 문화권의 노동 자들보다 조금 수월할 수도 있다는 것이다. 본 연구에서도 집단주의 문화권으로 분류되는 한국 표본을 사용했기 때문에 고객을 상대할 때의 태도인 분리된 관심의 수준이 소진 및 냉소와 갖는 관계가 약했을 수 있다.

비록 분리된 관심이 소진이나 냉소를 유의 하게 설명하지는 못하였으나, 직업비효능감은 유의하게 설명하였다. 기존의 많은 선행연구 들은 직업비효능감이 직무탈진의 다른 두 하 위요인들과는 질적으로 다를 수 있음을 시사 하였다(Cordes \& Dougherty, 1993; Halbesleben \& Demerouti, 2005). 그 중 하나가 직업비효능감 이 직무탈진 그 자체가 아니라 직무탈진의 결 과일 수 있다는 주장이다(Cordes \& Dougherty, 1993). 직업비효능감이 직무탈진의 결과까지는 아니더라도, 수행에 대한 평가를 나타낸다는 점에서 개념적으로 소진 및 냉소와 구분된다 (Maslach et al., 2001). 이러한 차이에 의해서 다른 하위요인에서는 관찰되지 않은 결과가 나타났을 수 있으며, 이는 분리된 관심이 적 어도 직업비효능감에 대한 개입에는 유용할 수 있음을 암시한다. 높은 분리와 높은 관심 의 조합은 낮은 분리와 낮은 관심의 조합보다 감소된 수준의 직업비효능감과 관련되었다.
분리된 관심이 처음에 적용된 의료계의 종사 자들은 스트레스가 큰 상황에서 대처 능력을 높이기 위해 가져야 할 태도로서 분리된 관심 에 대해 교육받은 사례가 있다(Fluttert et al., 2010a; Fluttert et al., 2010b). 이와 비슷하게, 의 료 종사자에 국한되지 않더라도 고객응대 업 무를 하는 종사자들에게 정서조절전략으로서 분리된 관심을 교육하여 직업비효능감의 감소 를 예방하는 것이 가능하다.

\section{연구 2}

\section{분리된 관심의 준거변수로서 직무열의}

현재까지의 분리된 관심 연구들은 주로 분 리된 관심이 근로자 직무탈진에 어떤 영향 을 미치는지를 살펴봤다(Greer \& Greer, 1992; Lampert \& Glaser, 2018; Lampert et al., 2019). 그러나 Lampert 등(2019)은 직무열의와 같은 직원의 동기부여 요소에 초점을 맞춘 향후 연 구가 유익할 수 있다고 제안한다.

산업 및 조직심리학 분야에서 긍정적인 결 과변수들에 대한 관심이 높아짐에 따라, 직무 열의는 매우 중요한 주제가 되었다(Bakker et al., 2008). 고객응대 업무에서 직무열의는 고객 만족에 긍정적인 영향을 미치기 때문에 특히 중요하다(Harter et al., 2002). 직무열의는 직 무탈진의 반대 개념으로 처음 소개되었으며 (Maslach et al., 2001), 일과 관련된 긍정적인 마음 상태로 정의된다(Schaufeli, 2003). 직무열 의의 세 가지 하위요인은 활력(vigor), 헌신 (dedication), 그리고 몰두(absorption)이다. 활력은 높은 에너지를 말하고, 헌신은 일에 관련된 열정적 관여를 뜻하며, 몰두는 일에 집중하는 
것을 의미한다(Bakker et al., 2008). 활력과 헌 신은 직무탈진의 두 핵심 차원인 소진과 냉소 의 정반대 개념이다(Schaufeli et al., 2002). 이처 럼 직무열의의 세 하위요인은 개념적으로 구 분된다(Schaufeli \& Bakker, 2004). 나아가, 국내 직장인들 대상의 선행연구들은 직무열의 하위 요인들이 차별적 예측모형을 보인다는 것을 밝혔다(Jang \& Park, 2018; Park et al., 2021). 따 라서 본 연구에서도 하위요인을 구분하여 조 사할 필요가 있다.

분리된 관심에 대한 이전 연구(Lampert et al., 2019; Lampert \& Glaser, 2018; Lampert \& Unterrainer, 2017)는 분리와 관심의 적절한 균 형이 분리된 관심에서 가장 중요하다는 것을 보여준다. 분리와 관심의 불일치 상황에서, 고 객에 대한 정서적 분리가 관심보다 높으면 종 업원은 고객의 문제를 공감적으로 파악하고 해결하려는 헌신적이고 몰입적인 자세를 취하 기 힘들 것이다. 반면, 관심이 분리보다 더욱 높을 경우 정서적 에너지를 끊임없이 소모하 게 된다(Lampert \& Glaser, 2018). 이는 지속적 에너지 수준인 활력의 저하로 나타나는 등 전 반적인 직무열의 수준이 감소할 것이다. 따라 서 본 연구는 분리와 관심 수준이 일치하는 상황이 직무열의에 가장 이상적이라고 판단하 여 다음과 같이 가설을 세웠다.

가설 4. 분리와 관심이 일치할수록 직무열 의(a. 활력, b. 헌신, c. 몰두)가 증가할 것이고, 일치하지 않을수록 직무열의가 감소할 것이다.

직무열의는 분리와 관심의 일치뿐만 아니 라, 일치의 수준에 따라서도 달라질 수 있다. 즉, 분리와 관심이 일치하는 경우에도 높은 분리-높은 관심의 일치와 낮은 관심-낮은 분리
의 일치는 서로 다른 결과를 가져올 수 있다. 표면행위와 내면행위를 구별하는 정서노동에 대한 연구들은 일관적으로 내면행위가 직무열 의에 긍정적인 영향을 미친다는 것을 보여준 다(Grandey, 2000; Hülsheger \& Schewe, 2011). 내 면행위는 표면행위와는 달리 정서노동에서 요 구되는 감정과 일치하는 진실된 감정이다 (Hochschild, 2012). 이와 비슷하게, 분리된 관심 의 관심은 고객에 대한 이해에서 비롯된 진정 한 공감이다(Halpern, 2001). 따라서 높은 관심 은 높은 직무열의로 이어질 수 있다. 그러나 관심이 높을 때, 긍정적인 결과를 유지하기 위해서는 관심의 부정적인 결과를 방지하기 위한 규제 전략인 분리 또한 높아야 한다. 따 라서 높은 관심과 높은 분리가 공존하는 경우 직무열의가 가장 높을 것으로 예상한다.

이와는 대조적으로, 낮은 분리와 낮은 관심 이 공존할 경우 종업원들의 직무열의 또한 낮 을 것으로 예상한다. 고객에 대한 공감적 관 심이 떨어질 경우, 고객과 적절한 관계를 구 축하기 어려울 수 있다(Dutton et al., 2014). 관 심이 낮은데 분리 또한 낮은 경우 역시 별로 도움이 안 될 가능성이 있다. 비록 관심이 낮 더라도 고객의 상황이 극단적으로 나빠서 고 객의 스트레스가 크다면, 낮은 분리는 스트레 스가 큰 고객응대 상황에 지나치게 마음을 쓰 게 해서 피로감과 정서적 소진을 유발할 수 있다(Figley, 2002). 고객과 이상적인 관계 구축 은 어려우면서도 고객응대 상황에서 피로를 느낀다면 직원의 직무열의는 떨어질 것이다. 따라서 분리와 관심이 일치할 경우에도 둘 다 낮은 수준에서 일치한다면 직무열의가 낮을 것이다.

가설 5. 분리와 관심이 낮은 수준에서 일치 
할 경우에 비해, 분리와 관심이 높은 수준에 서 일치할 경우 직무열의(a. 활력, b. 헌신, c. 몰두)가 증가할 것이다.

\section{직무통제의 조절효과}

$\operatorname{Karasek}(1979)$ 은 직무통제를 작업 과정에 대 해 일정 정도의 권한을 가질 수 있는 잠재적 능력으로 정의했다. 직무통제는 스트레인 (strain)에 영향을 미칠 수 있는 중요한 직무특 성 중 하나이다(Elsass \& Veiga, 1997; Karasek, 1979). Karasek(1979)은 그의 직무요구-통제(job demands-control, JDC) 이론에서 직무요구가 스 트레인을 증가시키지만, 직무통제가 높다면 이러한 관계가 완충될 수 있다고 주장하였다. 이와 같은 주장이 학자들에게는 논리적으로 수용된 반면, 경험연구에서는 강력하게 지지 되지는 않았다(Häusser et al., 2010; Van der Doef \& Maes, 1999).

이후에 Bakker와 Demerouti(2007)의 JD-R 이 론은 직무열의 등의 정신건강을 예측하는 요 인으로서 직무통제를 포함한 직무자원의 역할 을 설명하였다. JD-R 이론은 JDC 이론과 다르 게 여러 가지 직무요구 및 직무자원을 활용하 였고, 다양한 직무자원들이 직무요구와 상호 작용해서 종업원 웰빙을 예측할 수 있음을 시 사한다(Bakker \& Demerouti, 2007). 즉, 직무요 구는 직무열의를 낮추는 부적 관계를 갖지만, 직무자원이 존재한다면 그 관계가 완화될 수 있고, 직무요구의 종류에 따라 필요한 직무자 원은 달라질 수 있다. 이와 같은 JD-R 이론에 기반하자면, JDC 이론에서는 약하게 지지된 직무통제의 완충적 조절효과가 다른 종류의 관계에서는 나타날 수 있다. 즉, 직무통제의 상호작용 효과가 직무스트레스원, 결과변수,
혹은 표본특성 등 다른 조건에 의해 결정될 수 있다. 예를 들어, 치과의사 대상의 연구에 서 직무열의를 예측함에 있어 직무통제가 다 른 직무스트레스원과는 상호작용을 보이지 않 았으나, 물리적 업무환경과는 상호작용을 하 였다(Hakanen et al., 2005).

Hochschild(2012)는 자신의 저서 "The managed heart: Commercialization of human feeling" 에서 고객 응대 종업원들이 직무와 관련된 상황을 더 잘 통제할 수 있다면 정서노동의 부정적 결과를 줄일 수 있을 것이라고 주장한다. 고객응대를 하는 종업원들은 지속적으로 정서를 조절하고 특정 지침대로 행동해야 한다는 요구를 받고 있기 때문에(Hochschild, 2012), 높은 직무요구 상황임에도 불구하고 직무통제가 높은 경우 긍정적인 결과로 이어질 수 있다. 또, 직장에 서 위협적인 상황들(예를 들어, 무례한 고객을 상대할 경우 등)에 노출될 경우에도 직무통제 가 높을 경우 부정적인 결과로 이어지는 것을 방지할 수 있다(Ganster, 1989). 따라서 정서노 동 상황에서는 결정권한(decision authority) 등을 포함한 직무통제가 적절한 자원이 될 수 있다. 반대로, 직무를 전반적으로 추진하는 방식 등 에 대한 권한이 적을 경우, 고객응대 업무 직 원들은 일정 수준의 활력과 일에 대한 헌신 및 몰두 상태를 유지하기 위해 고객을 대하는 개인적인 태도 혹은 정서조절방략에 더욱 의 존할 것이다. 종합적으로, 높은 직무통제를 가 진 서비스 응대자들은 고객에 대한 분리 및 관심의 일치 혹은 불일치와 관계없이 일정한 직무열의를 유지할 수 있다. 다시 말해, 높은 직무통제를 지각하고 있다면, 분리와 관심의 수준이 일치하지 않을 때뿐만 아니라 분리와 관심이 모두 낮을 때에도 직무열의가 낮아지 지 않을 것이라고 예상했다. 
가설 6. 분리된 관심과 직무열의(a. 활력, b. 헌신, c. 몰두)의 관계를 직무통제가 조절하여 직무통제가 낮을 경우에 비해 높을 경우 관계 가 더 약하게 나타날 것이다.

\section{방법}

\section{연구대상 및 절차}

연구 2의 대상은 연구 1 과는 독립적인 표집 으로, 고객응대업무를 수행하는 만 19세 이상 한국 주간 전일제 근무자로 설정했다. 대학 소속 생명윤리심의위원회의 승인을 득한 후, 온라인 설문조사회사의 패널을 통해 2020년 7 월에서 2020년 8월까지 한 달 간격으로, 총 두 번의 자기보고식 온라인 설문조사를 실시하였 다. 사전질문을 통해 조건에 부합하는 사람들 에게만 연구에 대한 설명서를 제공하였고, 동 의를 클릭한 사람에 한하여 본 설문에 참여할 수 있게 한 결과, 첫 번째 조사(Time 1)에서는 583명이 응답했고, 한 달 뒤(Time 2) 동일한 설문에 응답한 인원은 Time 1의 64.15\%인 374 명으로, 총 참여 인원은 374 명이었다.

본 조사에 참여한 사람들은 여성이 213명 (57.0\%)이었으며 평균 근속연수는 6.34 년 $(S D=$ $5.90)$, 평균 연령은 36.64 세였다 $(S D=8.73)$. 이 중 정규직은 $91.7 \%$ 였고, 약 절반정도가 기혼 이었다 $(175 ; 46.8 \%)$. 직업은 관리/지원(42.0\%), 영업(16.0\%), 건강/의료 서비스(13.6\%), 공무원 (6.4\%), 연구/개발(5.9\%), 기술(4.8\%), 생산(2.9\%), 그리고 기타(교육, 서비스, 마케팅 등; $8.3 \%$ )로 다양했다.

\section{측정도구}

분리된 관심. 분리된 관심을 측정하기 위 해 연구 1 의 한국형 분리된 관심 척도를 사용
하였다. 척도는 총 여섯 문항으로, 분리 세 문 항(“나는 일에서 나의 고객들과 관계를 맺지 만, 스스로에게 정서적인 부담감을 주지 않는 다”와 관심 세 문항(“고객들과 일을 할 때, 나 는 그들을 반복적으로 안심시킨다")으로 구성 된다. 각 문항들은 5점 척도로 측정되었다 $(1$ $=$ 매우 그렇지 않다, $5=$ 매우 그렇다). Time 1 의 자료로 확인적 요인분석을 시행한 결과, 두 잠재요인으로 구성된 모형의 적합도는 좋 았으며, $\mathrm{X}^{2}(8)=28.68, p<.001, \mathrm{CFI}=.97$, RMSEA $=.07$, SRMR $=.03$. 하나의 잠재요인 모형보다, $X^{2}(9)=275.50, p<.001, \mathrm{CFI}=$ $.65, \mathrm{RMSEA}=.23, \mathrm{SRMR}=.14$, 훨씬 더 우수 하게 나타났다, $\Delta \mathrm{x}^{2}(1)=246.82, p<.001$. 분 리와 관심의 신뢰도는 각각 Time 1 에서 .60 과 .67 , Time 2에서 .65와 .68로 나타났다.

직무열의. 직무열의를 측정하기 위해 Schaufeli 등(2002)의 Utrecht Work Engagement Scale 9 item (UWES-9)를 한국어로 번안한 Chang(2009)의 척도를 사용하였다. 직무열의는 활력, 헌신, 몰두의 세 가지 하위요인으로 구 성되어 있다. 척도는 총 15 문항으로, 이 중 활 력 다섯 문항(“직무상에서, 나는 넘치는 힘을 느낀다.”), 헌신 다섯 문항(“나의 직무를 수행 하는 데 있어서 나는 열정적이다."), 몰두 다섯 문항(“나는 집중해서 일을 할 때면 행복감을 느낀다.”)으로 구성된다. 본 연구의 표본에서 직무열의의 하위요인들을 구분하여 사용하는 것이 적합한지 살펴보기 위해서 Time 1 의 자 료를 사용하여 3 요인모형이 1 요인모형보다 더 좋은지를 확인하였다. 확인적 요인분석 결과, 세 개의 하위요인이 서로 상관관계에 있으면 서 독립된 요인구조모형이 괜찮은 수치를 보 였다, $\mathrm{X}^{2}(24)=229.34, p<.001, \mathrm{CFI}=.95$, 
RMSEA $=.12, \mathrm{SRMR}=.04$. 모든 문항이 하나 의 잠재요인으로 수렴하는 모형의 경우 이보 다 나쁜 적합도를 보였다, $x^{2}(27)=501.56, p$ $<.001$, CFI $=.89$, RMSEA $=.17$, SRMR $=$ .06. 두 모형 간 차이는 통계적으로 유의했기 때문에, $\Delta \mathrm{x}^{2}(3)=272.22, p<.001$, 이후의 모 든 분석에서 세 하위요인을 구분하여 활용하 였다. 각 문항들은 5점 척도로 측정되었으며(1 $=$ 매우 그렇지 않다, $5=$ 매우 그렇다), 활력, 헌신, 그리고 몰두의 신뢰도는 각각 순서대로 Time 1에 .84, .84, .85로, Time 2에 .87, .86, .85 로 나타났다.

직무통제. 직무통제를 측정하기 위해 Lee(2016)가 한국어로 번안한 Van Yperen과 Hagedoorn(2003)의 척도를 사용하였다. 척도는 총 여덟 문항으로, "나는 업무를 수행할 때 추 진 방법을 선택할 권한이 있다.” 등의 문항들 로 구성된다. 각 문항들은 5점 척도로 측정되 었으며 $(1=$ 매우 그렇지 않다, $5=$ 매우 그렇 다), 신뢰도는 Time 1에서 .89, Time 2에서 .91 로 나타났다.

통제변수. 근속연수는 고객응대업무를 수 행하는 직무에서 본 연구의 결과변수인 직무 열의와 보통 상관관계가 큰 변수 중 하나이다 (e.g., Chen \& Kao, 2012, Havens et al., 2013). 이에 따라 근속연수와 결과변수인 직무열의 세 하위요인 간 상관을 산출하였다(Becker et al., 2016). 근속연수는 "귀하의 현 직장에서의 근무기간은 어느 정도 되십니까?”로 측정되었 고, 분석에서는 단위를 개월로 변환하여 사용 하였다. 근속연수와 Time 2 직무열의 세 하위 요인 모두가 유의한 상관을 보였기 때문에 근 속연수를 통제변수로 선정했다.

\section{자료분석}

분리된 관심(Time 1)과 직무열의(Time 2)의 관계를 검정하기 위해 연구 1 과 같이 직무열 의의 각 하위요인에 대해 다항회귀분석을 실 시한 후, 세 회귀분석의 전체 모형이 유의한 지 확인하였다. 모든 모형이 유의하였기 때문 에, 반응표면그래프를 그려 삼차원적 관계의 기울기와 곡률을 살펴보았다. 근속연수를 통 제변수로 사용해 분석했을 때, 첫 번째 단계 에서 근속연수의 설명력은 각각 활력에서 .05 , 헌신에서 .04, 몰두에서 .05로 나타났다. 통제 변수가 있는 두 번째 단계의 유의도와 통제변 수가 없는 첫 번째 단계의 유의도가 모두 유 의한 것으로 나타나서 이후부터는 통제변수가 없는 결과를 보고하였다. 즉, 통제변수가 있을 때와 없을 때의 가설에 대한 결과 차이가 거 의 없었기 때문에 표 5에는 통제변수를 제외 한 결과를 제시했다. 가설 4가 지지되기 위해 서는 불일치선의 기울기가 유의하지 않고, 곡 률이 유의해야 한다. 또, 가설 5 가 지지되기 위해서는 일치선의 기울기가 정적으로 유의하 고, 곡률이 유의하지 않아야 한다.

직무통제(Time 1)의 조절효과를 검정하기 위 해서는 직무통제의 중간값(median; $n=36$ )을 기준으로 3.50 보다 높은 직무통제 집단 $(n=$ 155)과 3.50 보다 낮은 직무통제 집단 $(n=183)$ 으로 나눈 뒤, 각각의 집단에 동일한 다항회 귀분석을 실시하여 두 모형에서의 설명력 $\left(R^{2}\right)$ 을 비교하였다. 근속연수를 통제했을 때, 근속 연수의 설명력은 직무통제가 낮을 때 각각 활 력에서 .01 , 헌신에서 .02 , 몰두에서 .03 으로 나 타났고, 직무통제가 높을 때 활력에서 07 , 헌 신에서 .05, 몰두에서 .04로 나타났다. 세 하위 요인 모두에서 통제변수의 유무가 다항회귀 전체 모형의 유의도에 크게 영향을 주지 않았 
다. 이에 따라 표 6에도 통제변수를 제외한 결과를 보고하였다. 가설 6이 지지되기 위해 서는 낮은 직무통제 집단에서 분리된 관심의 설명력이 유의한 반면, 높은 직무통제 집단에 서 분리된 관심의 설명력은 유의하지 않아야 한다. 나아가, 세부적인 조절효과 양상을 확인 하기 위해 반응표면그래프를 그리고 참조선의 기울기와 곡률을 계산하여 낮은 직무통제 집 단과 높은 직무통제 집단에서 삼차원적 관계 가 구체적으로 차이를 보이는지 살펴보았다.
결과

표 4에 연구 2 변수들의 평균, 표준편차, 내 적일치도 및 각 변수 간 상관계수를 제시하였 다. Time 1 의 분리와 Time 2의 활력, $r=.07$, $n s$, 헌신, $r=.11, p<.05$, 그리고 몰두, $r=$ $.12, p<.05$, 간 상관보다 Time 1 의 관심과 Time 2의 활력, $r=.26, p<.001$, 헌신, $r=$ .28, $p<.001$, 그리고 몰두, $r=.25, p<.001$, 간 상관이 더 컸다. 또한, Time 1 의 직무통제 는 Time 2 의 활력, $r=.35, p<.001$, 헌신, $r$

Table 4. Descriptive Statistics and Correlations between Study 2 Variables

\begin{tabular}{|c|c|c|c|c|c|c|c|c|c|c|c|c|c|}
\hline Variables & 1 & 2 & 3 & 4 & 5 & 6 & 7 & 8 & 9 & 10 & 11 & 12 & 13 \\
\hline 1. T1 D & & & & & & & & & & & & & \\
\hline 2. $\mathrm{T} 1 \mathrm{C}$ & $.15^{* *}$ & & & & & & & & & & & & \\
\hline 3. T1 VI & .02 & $.22^{* * * *}$ & & & & & & & & & & & \\
\hline 4. T1 DE & .09 & $.31^{* * * *}$ & $.73^{* * * *}$ & & & & & & & & & & \\
\hline 5. $\mathrm{T} 1 \mathrm{AB}$ & $.12^{*}$ & $.26^{* * * *}$ & $.70^{* * *}$ & $.80^{* * * *}$ & & & & & & & & & \\
\hline 6. T1 JC & $.17^{* *}$ & $.16^{* *}$ & $.43^{* * *}$ & $.37^{* * *}$ & $.37^{* * * *}$ & & & & & & & & \\
\hline 7. T2 D & $.45^{* * *}$ & $.15^{* *}$ & .02 & $.12^{*}$ & $.14^{* *}$ & .06 & & & & & & & \\
\hline 8. $\mathrm{T} 2 \mathrm{C}$ & $.13^{*}$ & $.60^{* * *}$ & $.16^{* *}$ & $.25^{* * *}$ & $.18^{* * * *}$ & $.10^{*}$ & $.29^{* * *}$ & & & & & & \\
\hline 9. $\mathrm{T} 2 \mathrm{VI}$ & .07 & $.26^{* * *}$ & $.69^{* * * *}$ & $.56^{* * *}$ & $.56^{* * * *}$ & $.35^{* * * *}$ & $.11^{*}$ & $.22^{* * * *}$ & & & & & \\
\hline 10. $\mathrm{T} 2 \mathrm{DE}$ & $.11^{*}$ & $.28^{* * *}$ & $.62^{* * *}$ & $.67^{* * *}$ & $.66^{* * *}$ & $.30^{* * *}$ & $.17^{* *}$ & $.23^{* * *}$ & $.76^{* * *}$ & & & & \\
\hline 11. $\mathrm{T} 2 \mathrm{AB}$ & $.12^{*}$ & $.25^{* * *}$ & $.58^{* * *}$ & $.59^{* * * *}$ & $.65^{* * *}$ & $.32^{* * *}$ & $.14^{* *}$ & $.20^{* * * *}$ & $.72^{* * * *}$ & $.83^{* * *}$ & & & \\
\hline 12. T2 JC & $.18^{* *}$ & .06 & $.34^{* * * *}$ & $.28^{* * * *}$ & $.32^{* * *}$ & $.64^{* * *}$ & $.15^{* *}$ & $.13^{*}$ & $.44^{* * *}$ & $.40^{* * *}$ & $.44^{* * *}$ & & \\
\hline 13. Tenure & .00 & .01 & $.18^{* *}$ & .10 & $.13^{*}$ & $.17^{* *}$ & .09 & .05 & $.23^{* * *}$ & $.20^{* * *}$ & $.22^{* * *}$ & $.20^{* * *}$ & \\
\hline$M$ & 3.78 & 3.78 & 2.80 & 3.21 & 3.13 & 3.40 & 3.71 & 3.82 & 2.83 & 3.18 & 3.10 & 3.41 & 76.07 \\
\hline$S D$ & 0.61 & 0.60 & 0.86 & 0.78 & 0.82 & 0.67 & 0.62 & 0.55 & 0.86 & 0.81 & 0.82 & 0.70 & 70.77 \\
\hline$a$ & .60 & .67 & .84 & .84 & .85 & .89 & .65 & .68 & .87 & .86 & .85 & .91 & - \\
\hline
\end{tabular}


$=.30, p<.001$, 그리고 몰두, $r=.32, p<$ .001 , 모두와 유의한 상관을 보였다. 검사-재검 사 신뢰도를 나타내는 동일 변수의 한 달 간 격의 상관은 분리보다, $r=.45, p<.001$, 관 심에서 더 높게 나타났다, $r=.60, p<.001$.

\section{분리-관심 부합이 직무열의에 미치는 영향}

\section{에 대한 다항회귀 분석 결과}

표 5에 분리와 관심의 부합이 직무열의의 세 하위요인인 활력, 헌신, 몰두에 미치는 영 향을 확인하기 위해 실시한 다항회귀분석의 결과를 제시했다. 각 차원에 대한 반응표면그 래프는 그림 2에 제시했다.

분리-관심 부합과 활력 간의 관계에서 불일

Table 5. Detached Concern on Work Engagement

\begin{tabular}{|c|c|c|c|c|c|c|c|c|c|c|}
\hline \multirow{2}{*}{$\begin{array}{l}\text { Dependent } \\
\text { Variables }\end{array}$} & \multicolumn{5}{|c|}{$B$} & \multirow{2}{*}{$R^{2}$} & \multicolumn{2}{|c|}{$\mathrm{D}=\mathrm{C}$} & \multicolumn{2}{|c|}{$\mathrm{D}=-\mathrm{C}$} \\
\hline & $\mathrm{D}$ & $\mathrm{C}$ & $\mathrm{D}^{2}$ & $C \times D$ & $C^{2}$ & & Slope & Curvature & Slope & Curvature \\
\hline Vigor & -.03 & .23 & -.17 & $.38^{* * * *}$ & -.08 & $.12^{* * *}$ & .20 & .13 & .25 & $-.63^{* * *}$ \\
\hline Dedication & .10 & $.36^{* *}$ & -.11 & $.21^{* *}$ & -.09 & $.11^{* * *}$ & $.43^{* *}$ & .00 & .28 & $-.41^{* *}$ \\
\hline Absorption & .17 & $.33^{* *}$ & -.15 & $.18^{*}$ & -.10 & $.09^{* * *}$ & $.50^{* *}$ & -.06 & .17 & $-.42^{* *}$ \\
\hline
\end{tabular}

Note. $N_{2}=374 ;{ }^{*} p<.05,{ }^{* *} p<.01,{ }^{* * *} p<.001 ; B=$ unstandardized coefficient; $\mathrm{C}=$ concern, $\mathrm{D}=$ detachment.
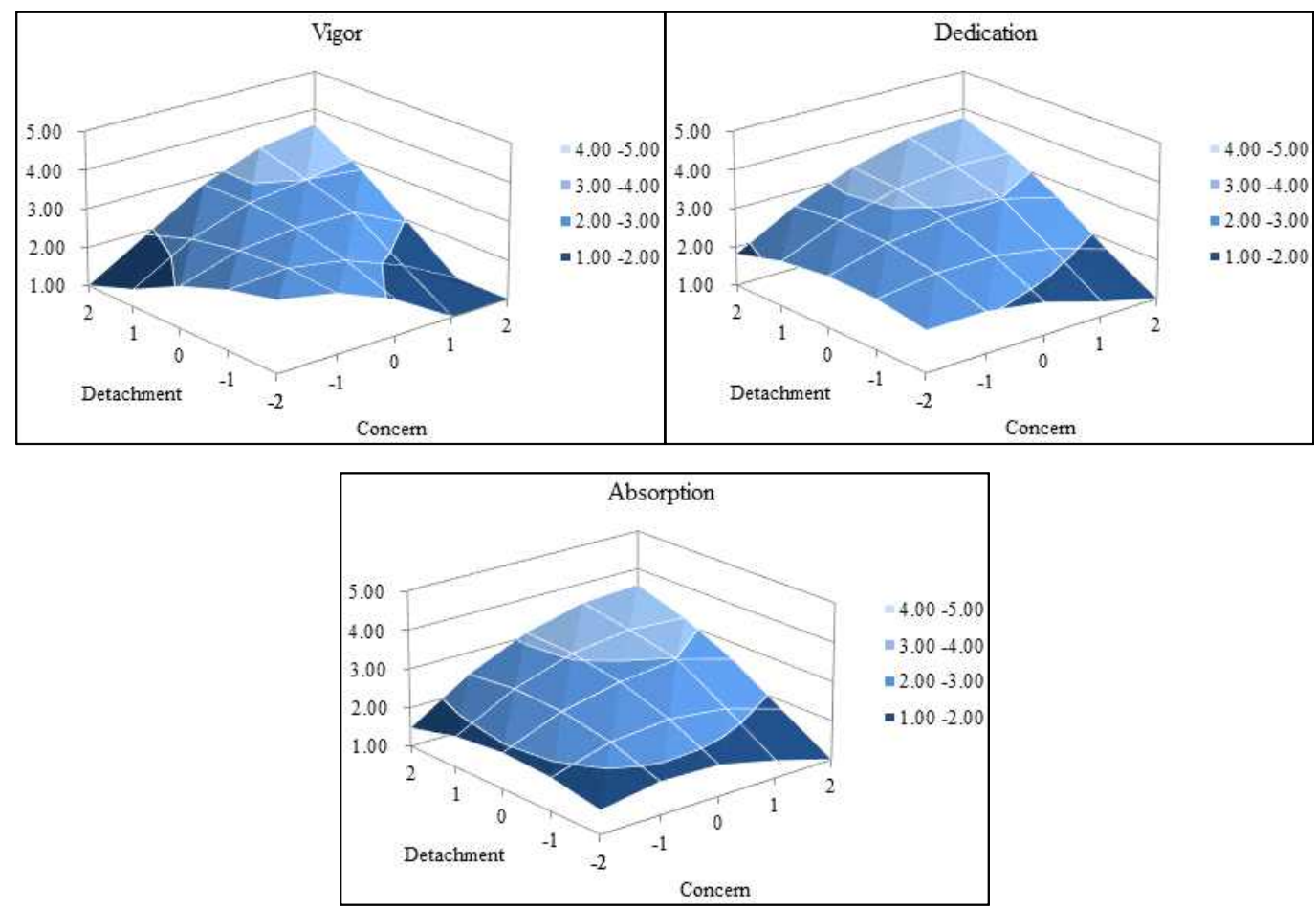

Figure 2. Detached concern on work engagement 
치선의 곡률은 유의했다, $b=-0.63, p<.001$. 한편, 불일치선의 기울기는 유의하지 않았다. 헌신의 경우에도, 불일치선의 곡률은 유의했 으나, $b=-0.41, p<.01$, 기울기는 유의하지 않았다. 몰두에서도, 불일치선의 곡률은 유의 한 반면, $b=-0.42, p<.01$, 기울기는 유의하 지 않았다. 그림 2를 보면, 세 하위요인에서 공통적으로 분리와 관심의 수준이 일치하지 않을 경우에 비해 일치할 경우 결과변수의 수 준이 높아지는 역U자형 관계를 볼 수 있다. 따라서 가설 4-a, 4-b, 4-c는 모두 지지되었다.

가설 5 를 검정하기 위해서는 그래프의 일치 선을 살펴봐야 한다. 활력에 대한 모형에서는 일치선의 기울기와 곡률 모두 유의하지 않았 다. 헌신의 경우, 일치선의 기울기는 정적으로 유의했고, $b=0.43, p<.01$, 곡률은 유의하지 않았다. 몰두의 경우에도, 일치선의 기울기는 정적으로 유의했고, $b=0.50, p<.01$, 곡률은 유의하지 않았다. 그림 2 를 보면, 헌신과 몰두 의 그래프에서는 일치선을 따라 분리와 관심 이 둘 다 높은 경우에는 결과변수의 수준이 높으나 둘 다 낮은 경우에는 낮아지는 것을
확인할 수 있다. 따라서 가설 5-b, 5-c는 지지 되었고, 가설 5-a는 지지되지 않았다.

\section{분리-관심 부합과 직무열의의 관계에서 직} 무통제의 조절효과

표 6에 직무통제를 높은 집단과 낮은 집단 으로 나누어 분리된 관심이 직무열의의 각 하 위요인에 미치는 영향에 대한 결과를 제시하 였다. 통제변수를 제외하고 분석했을 때, 직무 통제가 낮은 집단과, $R^{2}=.08, p<.05$, 높은 집단 모두 활력을 유의하게 설명했고, $R^{2}=$ $.19, p<.001$, 설명력은 오히려 직무통제가 높 은 집단에서 더 크게 나타났다. 헌신에서도, 직무통제가 낮은 집단과, $R^{2}=.10, p<.01$, 높은 집단 모두 모형이 유의했다, $R^{2}=.10, p$ $<.01$. 몰두의 경우, 직무통제가 낮은 집단에 서는 다항회귀모형이 유의했으나, $R^{2}=.11, p$ $<.01$, 높은 집단에서는 모형이 유의하지 않 았다, $R^{2}=.05, n s$. 집단에 따른 구체적인 관 계양상을 살펴보기 위해 반응표면그래프를 그 려 살펴보았다.

그림 3에서 활력을 설명하는 모형에서 두

Table 6. The Interaction Effect of Detached Concern and Job Control on Work Engagement

\begin{tabular}{|c|c|c|c|c|c|c|c|c|c|c|c|}
\hline \multirow{2}{*}{$\begin{array}{l}\text { Dependent } \\
\text { Variables }\end{array}$} & \multirow{2}{*}{$\begin{array}{c}\text { JC } \\
\text { Levels }\end{array}$} & \multicolumn{5}{|c|}{$B$} & \multirow{2}{*}{$R^{2}$} & \multicolumn{2}{|c|}{$\mathrm{D}=\mathrm{C}$} & \multicolumn{2}{|c|}{$D=-C$} \\
\hline & & $\mathrm{D}$ & $\mathrm{C}$ & $\mathrm{D}^{2}$ & $C \times D$ & $C^{2}$ & & Slope & Curvature & Slope & Curvature \\
\hline \multirow{2}{*}{ Vigor } & Low & -.02 & .09 & -.23 & $.29^{* *}$ & -.23 & $.08^{*}$ & .07 & .03 & .11 & $-.54^{* *}$ \\
\hline & High & .17 & $.64^{*}$ & -.17 & $.37^{*}$ & -.28 & $.19^{* * *}$ & .81 & -.08 & .47 & $-.82^{* *}$ \\
\hline \multirow{2}{*}{ Dedication } & Low & .11 & .22 & -.21 & $.28^{*}$ & -.08 & $.10^{* *}$ & .33 & -.02 & .11 & $-.57^{* *}$ \\
\hline & High & .23 & $.71^{*}$ & -.03 & -.07 & -.15 & $.10^{* *}$ & $.94^{*}$ & -.26 & .48 & -.11 \\
\hline \multirow{2}{*}{ Absorption } & Low & .21 & $.29^{*}$ & $-.26^{*}$ & .20 & -.06 & $.11^{* *}$ & $.49^{* *}$ & -.12 & .08 & $-.52^{* *}$ \\
\hline & High & .09 & .26 & -.04 & .11 & -.06 & .05 & .35 & .02 & .17 & -.21 \\
\hline
\end{tabular}


집단의 차이를 살펴보면, 직무통제가 낮을 때 와 높을 때 모두 관계의 양상 자체는 비슷하 게 나타났으나, 높은 집단에서 역U자형 관계 가 더 명확하였다. 즉, 주효과 분석에서와 마 찬가지로 일치선에서는 기울기와 곡률 모두 유의하지 않았고, 불일치선에서는 곡률만 유 의하였으나, 그 정도가 직무통제가 높을 때 더 컸다. 종합적으로, 직무통제의 수준에 따라 관계의 효과크기가 다르게 나타나서 조절효과 가 나타났으나, 가설과 다른 양상이었기 때문 에 가설 6-a는 지지되지 않았다.

그림 4 에서 분리된 관심과 헌신의 관계를 살펴보면, 직무통제가 낮을 때에만 불일치선 을 따라서 분리와 관심의 수준이 부합하지 않
을수록 헌신이 감소하는 역 U자형 관계가 나 타났다. 직무통제가 높을 때에는 불일치선에 서 그런 효과가 나타나지 않았다. 반면, 직무 통제가 높을 때에는 일치선에 따라 분리와 관 심이 모두 증가할 때 헌신이 증가했지만, 직 무통제가 낮을 때에는 해당 현상이 나타나지 않았다. 따라서 헌신에서도 직무통제의 조절 효과가 나타났으나, 가설과 다른 양상이었기 때문에 가설 6-b는 지지되지 않았다.

그림 5 에서 분리된 관심과 몰두의 관계를 살펴보면, 직무통제가 낮을 경우 불일치선의 양방향에서 몰두가 낮아지며, 일치선을 따라 분리와 관심이 증가할수록 몰두가 높아졌다 즉, 주효과에서 나타난 관계양상이 동일하게

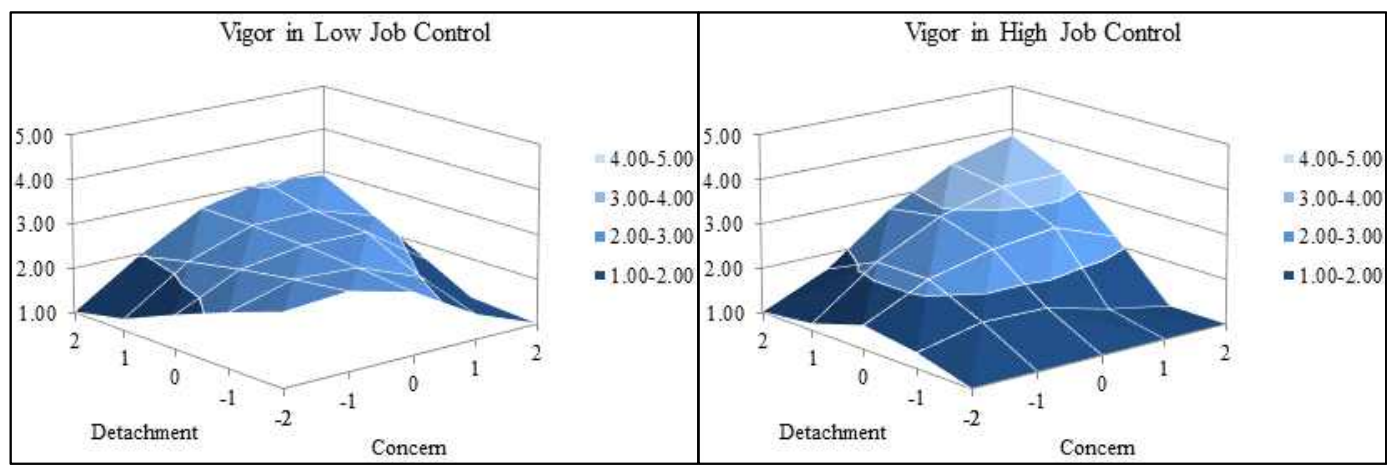

Figure 3. Detached concern and job control on vigor

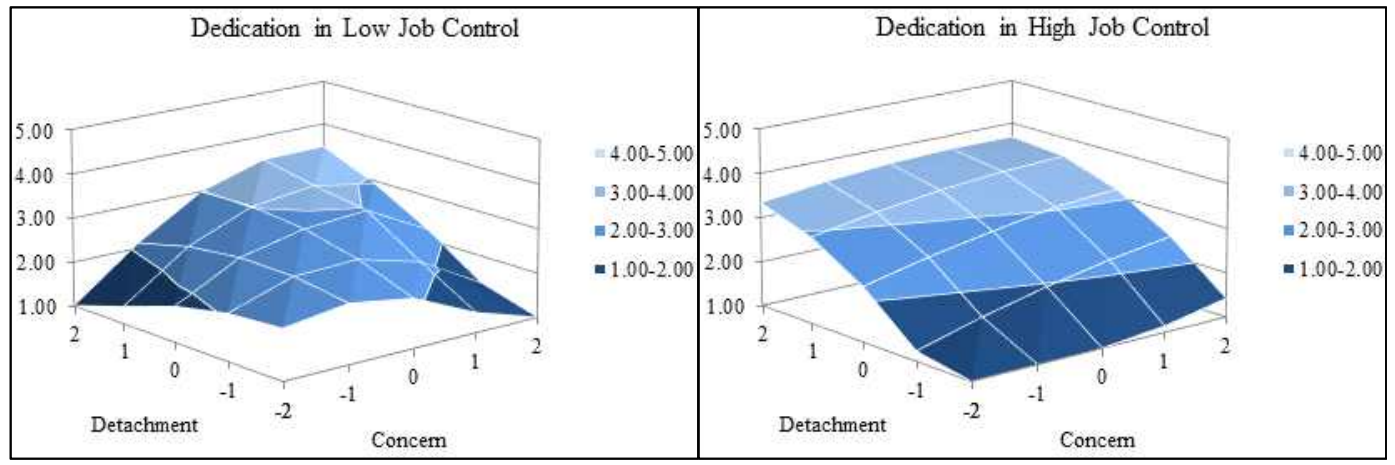

Figure 4. Detached concern and job control on dedication 


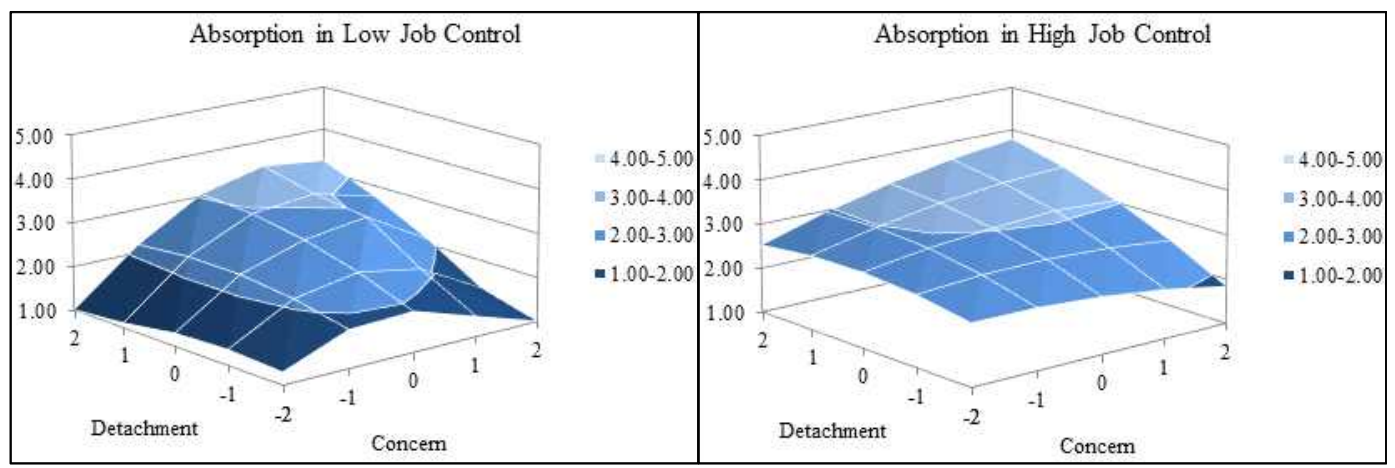

Figure 5. Detached concern and job control on absorption

나타났다. 반면, 직무통제가 높을 경우 다항회 귀모형이 유의하지 않아 뚜렷한 삼차원적 관 계가 나타나지 않았고, 참조선의 기울기와 곡 률 모두 유의하지 않았다. 따라서 가설 6-c이 지지되었다.

논의

연구 2 는 연구 1 에서 번역 및 타당화한 한 국판 분리된 관심 척도를 사용해 분리된 관 심과 긍정적 결과변수인 직무열의의 관계를 살펴보고, 직무통제가 해당 관계의 경계조건 (boundary condition)으로 작용하는지 확인했다. 이를 알아보기 위해 19세 이상 전일제 직장인 들 중 고객응대 업무를 수행하는 사람 374 명 을 대상으로 한 달 간격, 총 두 번의 자기보 고식 설문조사로 자료를 수집해 분석했다. 연 구 결과, 본 자료에서는 분리와 관심이 직무 열의의 세 하위요인과 모두 관계가 있었다. 특히, 분리와 관심이 불일치할 경우에 비해 일치할 경우 직무열의의 세 하위요인 모두가 증가했다. 이는 관심에 따른 적절한 수준의 분리가 필요하다는 분리된 관심 연구의 핵심 내용인 균형의 중요성을 지지한다.
헌신과 몰두에서는 분리와 관심이 일치할 경우에도 둘 다 낮은 수준보다 높은 수준에서 일치하는 것이 직무열의를 높일 수 있다는 것 을 확인했다. 불균형보다는 균형의 상태가 더 좋지만, 균형의 상태라도 다 같은 결과로 이 어지는 것이 아니라는 의미이다. 즉, 고객에 대한 공감적 관심이 높아서 고객의 요구에 성 공적으로 응대하는 동시에 비슷한 수준의 높 은 분리로 인해 피로감 역시 방지한다면, 본 인이 수행하는 고객응대업무에 대한 헌신 및 몰두가 높아질 수 있다. 반면, 균형이라도 해 도 분리와 관심이 모두 낮다면 직무에 대한 헌신과 몰두는 상대적으로 떨어진다. 한편, 활 력에서는 분리와 관심이 일치할 때의 수준에 따라 유의한 영향을 받지 않았다. 활력은 직 무열의 중 높은 에너지 수준과 관련된 차원으 로(Bakker, 2011), 헌신이나 몰두와는 다른 특 성을 가진다(Schaufeli \& Bakker, 2004). 이에 따 라 각각의 하위요인을 예측하는 요인들 또한 다를 수 있다. 예를 들어, 활력은 다른 하위요 인들보다 일-가정 갈등 및 성취회복경험에 의 해 더 많은 영향을 받았다(Park et al., 2021). 이와 비슷하게, 활력은 다른 하위요인에 비해 분리와 관심의 상호작용에 의해서는 영향을 
덜 받았다. 하지만 활력 또한 분리 수준과 관 심 수준이 가장 높은 점에서 일치할 때 가장 높은 경향을 보였다. 즉, 효과크기는 유의도 수준에 미치지 않았으나, 일치선에서의 관계 양상은 다른 하위요인들과 비슷하게 나타났다.

분리된 관심과 직무열의의 관계에서 직무통 제의 조절효과가 관찰되기는 하였으나, 직무 열의의 하위요인에 따라 모두 양상이 달랐다. 우선, 활력에서는 직무통제가 높을 경우에 분 리된 관심의 효과가 약화되지 않고 오히려 강 화되었다. 이는 직무통제가 분리된 관심이 직 무열의에 갖는 효과를 완충할 것이라는 본 연 구의 가설과 반대 방향의 결과이다. 둘째, 헌 신의 경우, 분리된 관심의 효과크기 자체는 비슷하였다. 그렇지만 직무통제가 낮으면 분 리된 관심의 불일치 수준에 의해 더 영향을 받는 반면, 직무통제가 높으면 분리된 관심의 일치 수준에 의해 더 영향을 받았다. 마지막 으로, 몰두에서는 직무통제가 낮을 경우에 비 해 높을 경우에 분리된 관심의 효과가 약화되 어 가설이 지지되었다. 이는 높은 요구가 직 무열의의 저하로 이어지는 것을 직무통제가 완충한다는 JD-R 이론(Bakker \& Demerouti, 2007)과 일치한다. 결과들을 종합하면, 가설과 모두 일치하는 방향은 아니지만 직무통제에 따라 분리된 관심과 직무열의의 관계 양상이 달라지기 때문에 직무통제가 해당 관계에서 조절효과를 가진다고 해석할 수 있다.

직무통제의 조절효과가 가설과 다르게 나타 나기도 하였지만, 직무통제가 자원으로 작용 할 수 있음을 보여준다. 특히, 일에 대한 높은 통제 권한은 서비스 응대자가 고객에 대한 분 리된 관심의 수준에 영향을 덜 받고 직무에 몰두할 수 있게 하였다. 또한, 이원상관 결과 는 직무통제가 높으면 한 달 후의 활력, 헌신,
그리고 몰두 모두가 높은 수준을 나타낼 수 있음을 보여 주었다. 이는 직무통제가 직무열 의에 정적 영향을 미친다는 다른 종단연구의 결과와도 일치한다(Mauno et al., 2007). 나아가, 직무통제가 근로자의 정신건강에 긍정적인 영 향을 미칠 수 있고, 이런 효과가 서비스 근로 자에게서 더 크게 나타날 수 있다는 연구 결 과와도 일맥상통한다(Park et al., 2014). 따라 서 조직은 고객응대 근로자들에게 직무통제 를 더 제공하여 직무열의 등을 높일 수 있다. 혹은, 조직에서 직무통제를 공식적으로 제공 해 주지 않더라도 근로자 스스로 잡 크래프팅 (job crafting) 등을 통해 직무통제의 범위를 더 넓힐 수도 있을 것이다(Tims \& Bakker, 2010).

\section{종합논의}

지금까지 고객서비스 업무에 대한 연구들은 보통 근로자의 표면행위와 내면행위에 초점을 맞췄다(Grandey, 2000; Hochschild, 2012). 이에 반해 본 연구는 고객을 대하는 태도와 관련된 분리된 관심이라는 개념을 소개했다. 연구 1 에서는 분리된 관심 척도를 번역한 후, 타당 도를 확인하기 위해 분리된 관심과 직무탈진 의 관계를 분석했다. 연구 결과, 분리된 관심 의 두 하위요인인 분리와 관심은 독립적인 차 원으로 확인되었고, 분리와 관심의 수준은 서 로 상호작용하여 직업비효능감을 유의하게 설 명하였다. Lampert와 Glaser(2018)의 연구에서는 분리된 관심이 정서적 소진 또한 유의하게 설 명했으나, 본 연구에서는 유의하지 않았다. Lampert와 Glaser(2018)는 독일과 오스트리아의 표본을 사용하였는데, 직무특성이 직무탈진에 미치는 영향은 나라마다 다를 수 있다. 예를 
들어, 직무스트레스원이 소진과 비인격화에 미치는 영향이 캐나다 표본보다 중국 표본에 서 더 적은 것으로 나타났고(Jamal, 2005), 고 객응대 시 표면행위와 소진 및 냉소의 관계가 미국 표본보다 중국 표본에서 더 낮았다(Allen et al., 2014). 즉, 개인주의적인 서양의 문화권 에서 스트레스원으로 작용할 수 있는 직무특 성이 집단주의적 동양 문화권에서는 직무탈진, 특히 소진과 냉소로 이어지지 않을 수 있다. 요컨대, 동일한 직무특성을 경험하더라도 소 속 국가의 문화에 따라 다르게 지각하거나 해 석할 수 있고, 이에 따라 결과에 대한 직무환 경의 효과가 문화에 달라지는 조절효과가 나 타날 수 있다(Peretz \& Fried, 2012). 본 연구에 서는 고객응대 업무를 수행할 때의 태도이자 정서조절전략인 분리된 관심이 소진 및 냉소 를 유의하게 설명하지 않았다. 분리된 관심은 직무특성이 아니라 태도라는 점에서 전술한 연구들과는 다르지만, 전통적으로 개인의 정 서를 그대로 드러내는 것보다 사회적인 조화 를 위해 집단의 규범에 따라 행동하는 것이 익숙한 집단주의 성향의 사회(Hofstede, 2011) 에서는 조직을 위해 고객을 응대하는 과정에 서 분리와 관심의 불일치가 일어난다고 해서 소진이나 냉소로 이어지지 않을 수 있을 것이 다. 즉, 자신의 의지가 아니라 조직에서 요구 하는 규범에 따라 고객들에게 공감적 관심을 보일 때, 개인적인 피로를 해소시키기 위한 분리가 관심과 비슷한 수준이 아니라고 해도 조직의 규범을 우선시하는 것이 더 자연스러 운 문화의 영향을 받아서 일에 냉소적인 태도 로 임하거나 정서적으로 소진되지 않을 가능 성이 있다. 따라서 본 연구에서 기존 서양권 에서 진행된 분리된 관심 연구와 결과가 다르 게 나타난 것은 표본의 문화적 차이에 기인할
수 있다.

연구 2 에서는 한 달 간격의 종단연구를 통 해 분리된 관심과 긍정적인 결과변수인 직무 열의의 삼차원적 관계를 살펴봤다. 또, 직무통 제가 조절변수로 작용해 그 관계를 약화시키 는지 알아봤다. 다항회귀분석 결과, 분리와 관심의 일치/불일치는 한 달 후의 직무열의에 영향을 미쳤다. 나아가, 직무열의와의 관계에 서 직무통제는 조절변수로 작용해 각 차원에 따라 관계의 양상을 변화시켰다. 직무통제 는 중요한 직무자원으로, 특히 정서노동자들 의 웰빙을 위해 필요한 자원이다(Hochschild, 2012). 분리된 관심과 직무열의의 관계에서 직 무통제의 조절효과는 직무열의의 세 하위요인 에 따라 달랐는데, 이는 각 요인들의 특성으 로 인한 결과일 수 있다. 직무열의의 활력은 에너지나 행동적(behavioral-energetic) 측면, 헌 신은 정서적(emotional) 측면, 몰두는 인지적 (cognitive) 측면을 각각 측정한다(Schaufeli, 2012). 이처럼 세 가지 하위요인이 각각 직무열의의 다른 측면을 측정하기 때문에 직무통제의 조 절효과가 각 요인별로 차이를 보였을 것이다. 활력에서는 직무통제가 높을 경우에 분리된 관심의 효과가 강화되었다. 헌신의 경우 직무 통제가 낮으면 분리된 관심의 불일치 정도에 의해 더 영향을 받는 반면, 직무통제가 높으 면 분리와 관심이 일치할 때 구체적으로 어느 점수에서 일치하는지에 의해 더 영향을 받았 다. 몰두에서는 가설과 일치하는 방향으로 직 무통제가 높을 경우 분리된 관심의 효과가 약 화되었다.

덧붙여, 연구 1 의 확인적 요인분석에서는 RMSEA 지수가 좋지 않은 결과에 대한 논의를 제시하고자 한다. RMSEA는 완벽한(포화) 모형 과 비교하는 절대적 수치 중 하나로, 자유도 
가 높거나(Hong, 2000; Kline, 2016) 혹은 대규 모 표본에 사용이 적합하다(Kline, 2016). 본 연 구에서 2 요인모형의 자유도는 낮은 편이고 $d f$ $=8$ ), 연구 1 은 상대적으로 작은 표본을 사용 하였다. 이럴 경우 $\mathrm{CFI}$ 등을 위주로 해석하는 것이 좋다(Hong, 2000). 연구 1의 RMSEA가 좋 지는 않지만 $\mathrm{CFI}$ 는 좋은 편이며, 1 요인모형과 의 비교에서 2 요인모형이 훨씬 더 우수한 결 과를 보였기 때문에 분리와 관심의 독립적 요 인구조를 의심할 이유는 없다. 나아가, 보다 큰 표본을 활용한 연구 2 에서는 2 요인모형의 결과가 모든 수치에서 좋게 나타났으므로, 이 러한 결과는 연구 1 의 표본이 요인분석을 위 해서는 다소 작았다는 한계점에서 온 것일 수 있다. 본문에 제시하지는 않았으나 연구 2 의 Time 2 자료로 재분석을 실시하였을 때도 매 우 우수한 적합도 수치가 나타났다.

본 연구의 학문적 의의는 다음과 같다. 첫 째, 서양 의료계에서 많이 연구되던 분리된 관심이라는 개념을 일반적인 서비스업으로 확대해서 고객응대 업무를 수행하는 직원이 고객에게 보이는 태도로 본 Lampert와 Glaser (2018)의 관점을 한국에 적용하였다. 분리된 관심을 측정할 수 있는 척도를 국내에 도입 하여 앞으로 관련 연구에 기초적인 도구를 제공했다는 함의가 있다. 둘째, 분리된 관심 이 지금까지 부정적인 결과변수의 예측변수 로 조사된 반면(Lampert et al., 2019; Lampert \& Glaser, 2018), 본 연구에서는 긍정적인 결 과변수인 직무열의를 사용해 분리와 관심의 일치/불일치 및 어느 수준에서 일치하는지가 종업원 긍정적 직무태도에 미치는 영향을 확 인하였다. 특히, 분리된 관심이 한 달 후의 직무열의에 미치는 종단적 효과를 조사하였 다는 점에서 횡단설계를 바탕으로 한 설문조
사에 비해 높은 내적타당도(internal validity)를 지닌다. 또한, 이러한 관계 분석에 다항회귀 와 반응표면그래프를 활용하여 분리된 관심 이 결과변수와 갖는 삼차원적 관계를 살펴보 았다. 분리와 관심을 동일선상의 정반대 개념 으로 인식하는 연구들이 존재하나(Coombs \& Goldman, 1973), 본 연구에서 분리와 관심은 독립적인 차원의 개념임을 밝혔기 때문에 분 리와 관심을 따로 측정하여 결과변수와의 삼 차원적인 관계를 살펴보는 것이 적절했다. 또, 반응표면그래프를 그려 관계 양상을 확인 함으로써 이원 상관 결과에 비해 더욱 세밀 한 관계 규명이 가능했다. 상관분석에서는 분 리가 직무열의의 세 하위요인과 갖는 상관이 높지 않았고, 활력은 매우 약한 상관을 보여 유의하지도 않았다. 그렇지만 분리와 관심의 상호작용으로 활력의 예측력을 살펴보았을 때는 약 $8 \%$ 의 설명량을 갖는다는 것이 관찰 되었다. 다항회귀와 반응표면그래프는 세 변 수 간 관계를 이렇게 입체적이고 다각적으로 분석할 수 있게 한다는 장점이 있고, 본 연구 는 이러한 장점을 십분 활용하였다. 마지막으 로, JD-R 이론과 동일한 맥락에서 분리된 관 심이 직무열의에 갖는 관계의 경계조건으로 직무통제가 작용할 수 있다는 것을 밝혔다 (Bakker \& Demerouti, 2007). 즉, 직무특성 요인 이 분리된 관심과 결과변수 간 관계를 변화 시킬 수 있다는 것을 확인하였다는 점에서 관련 연구의 범위를 확장하였다. 이는 특히 본 연구의 실무적 의의와도 연결된다.

본 연구가 지니는 실용적 함의는 다음과 같 다. 첫째, 고객응대 직무에서 종사자의 분리된 관심을 활용하여 결과변수에 대한 개입 가능 성을 시사한다. 분리된 관심은 개인의 심리적 웰빙뿐만 아니라 고객과의 상호작용에도 중요 
하다(Coulehan, 2012). 분리된 관심은 의료계 종 사자들을 대상으로 훈련이 가능한데, 특히 분 리된 관심 훈련은 고객의 적대성(aggression)을 누그러뜨리는 효과가 있다는 결과가 존재한다 (Fluttert et al., 2010a; Fluttert et al., 2010b). 이 와 같이 분리된 관심에 대한 개입이 가능하고, 본 연구에서 분리된 관심이 일반 서비스 종사 자들의 직무태도나 웰빙에도 영향을 줄 수 있 다는 것이 밝혀졌으므로, 일반 서비스 종사자 들을 대상으로 한 분리된 관심 프로그램 개발 도 고려해 볼 수 있다. 본 연구에서는 분리된 관심의 훈련 가능성을 직접적으로 조사하지는 않았으나, 분리 및 관심을 한 달 간격을 두고 두 번 측정하여 시간적 안정성을 확인할 수 있었다. 그 결과, 관심의 검사-재검사 신뢰도 (상관)보다 분리의 검사-재검사 신뢰도가 상 대적으로 더 변화의 여지가 있었다. 분리의 낮은 검사-재검사 신뢰도는 분리가 안정적인 특질이 아닌 고객에 대한 태도이자 정서조절 전략이며, 훈련을 통해 수준이 변화할 수 있 음을 시사한다. 즉, 분리 수준의 변화를 통해 분리된 관심의 균형을 맞추는 것이 용이할 수 있다. 따라서 고객응대 관련 교육 프로그 램을 구성할 때, 분리된 관심 훈련을 포함시 킨다면 종업원의 직무열의를 전반적으로 높 이거나 직업비효능감을 낮추는 데 도움이 될 것이다. 둘째, 본 연구의 결과는 고객응대 종 사자들에게 직무통제가 중요한 직무자원이 될 수 있다는 점을 시사한다. 훈련을 통해 고 객에 대한 태도인 분리된 관심의 수준 자체 를 이상적으로 변화시킬 수도 있으나, 이것이 어려운 상황에서는 직무재설계(job redesign) 등의 조직적 개입을 통해 직무통제와 같은 직무특성을 제공하여 긍정적인 결과를 이끌 어 낼 수 있을 것이다(Bond \& Bunce, 2001).
즉, 분리된 관심을 훈련시키는 것이 가능하다 고 해도, 모든 근로자들이 고객에 대해 높은 수준에서 일치하는 분리와 관심을 보이기는 쉽지 않다. 고객에 대한 태도를 교육시키는 것은 한계가 있을 수 있으므로, 직무자원의 역할을 하는 환경적 특성을 제공하여 분리된 관심의 불일치나 낮은 수준의 일치가 부정적 인 결과로 이어지는 것을 예방할 수 있을 것 이다.

본 연구에는 몇 가지 한계점이 존재한다. 첫째, 연구 1 에서는 적절하게 나타난 분리된 관심 척도의 내적일치도가 연구 2 에서는 수 용 가능한(acceptable) 정도였지만 높지 않았다 (Taber, 2018). 연구 1과 연구 2의 표본이 모두 온라인 조사회사의 패널에서 모집되어 비슷한 특성을 갖고 있기는 하지만, 연구 1 은 이미 모집된 표본 중 고객응대 업무 수행자를 선별 하여 본 연구의 변수들에 응답하도록 따로 조 사한 것이다. 반면, 연구 2 는 처음부터 고객응 대 업무를 한다고 답한 응답자만 연구에 참여 시켜 본 연구만을 위한 조사를 실시하였다. 따라서 연구 2 에서의 내적신뢰도가 낮게 나타 난 이유가 이렇게 다른 표집이나 연구설계에 서 기인했을 수 있다. 만약 표집이나 연구설 계의 문제가 아니라면 척도 번역의 문제일 가 능성도 존재한다. 본 연구자들은 역번역과 문 항일치도 결과를 고려하여 최대한 직역을 하 고자 하였다. 그렇지만 한국적 표현을 반영하 여 자연스럽게 의역을 한 문항이 다양한 응답 자들에게 더 보편적으로 수용될 수 있다. 이 를 확인하기 위해서 동일한 문항을 다양하게 번역하여 같은 표본에서의 심리측정적 속성을 비교해 볼 필요가 있다. 또한, 추후 연구들은 문항을 삭제하지 않은 원 척도를 사용해 한국 판 분리된 관심 척도의 신뢰도 및 타당도를 
재조사해 볼 것을 추천하며, 분석결과에 따라 서는 척도를 보완 및 재타당화하기를 제안한 다. 아쉽게도, 연구 2 에서는 연구 1 의 최종 문 항만을 사용하여 자료수집을 하였다. 척도의 낮은 신뢰도는 명백한 문제인 반면, 낮은 신 뢰도에도 불구하고 유의한 결과를 관찰하였다 는 것은 고무적이다. 낮은 신뢰도는 모수치의 효과크기를 체계적으로 감소시키기 때문에 (Schmidt \& Hunter, 2015), 낮은 신뢰도를 보인 척도로 본 연구와 같은 결과를 발견했다는 것 은 분리된 관심 자체가 직무열의에 미치는 효 과가 실제로는 더욱 클 수 있다는 것을 시사 한다. 척도의 신뢰도가 완벽할 수는 없으나, 신뢰도가 낮으면 낮을수록 효과크기는 그만큼 과소추정(downward bias)된다(Schmidt \& Hunter, 1996). 더욱 중요한 것은, 만약 낮은 내적일치 도가 척도 번역에서 기인된 문제점이라면, 연 구 1 에서도 내적일치도가 낮게 산출되었어야 한다. 그러므로 이러한 한계가 척도 번역의 문제일 가능성은 상대적으로 낮으며, 표집을 비롯한 연구설계의 문제라고 판단한다. 나아 가, 비록 다른 표본에서였으나, 본 연구에서는 분리된 관심이 직무탈진 및 직무열의와 갖는 관계가 차이가 나서 직무탈진보다는 직무열의 와의 관계가 더 명확하게 나타났다. 이것이 연구의 표본이나 설계에 의한 차이인지, 아니 면 한국 고객응대 근로자들에게서는 분리된 관심이 부정적 결과변수보다 긍정적 결과변수 에 더 많은 영향을 미치는지를 확인하기 위 해서는 더 많은 한국인 표본을 사용한 후속 연구가 필요하다. 또, 분리된 관심은 개인의 웰빙뿐만 아니라 성공적인 고객응대와도 관 련이 큰 개념이다(Cadge \& Hammonds, 2012; Coulehan, 2012). 현재까지의 분리된 관심 연구 들은 의료 분야에서 중점적으로 이루어졌지만,
이를 더 큰 산업 분야로 확장시켜 환자가 아 닌 일반 서비스를 이용하는 고객의 입장에서 종업원의 분리된 관심이 응대의 질에 영향을 미치는지 살펴보는 연구를 제언한다. 마지막 으로, 분리된 관심에 대한 최근 연구에 따르 면, 분리와 관심의 부합을 살펴보기보다 분리 와 관심 수준에 따른 프로파일(profile)을 높은 분리-높은 관심, 높은 분리-낮은 관심, 낮은 분 리-높은 관심, 중간 분리-높은 관심, 중간 분리 -낮은 관심의 다섯 가지로 나눠 연구하기도 했다(Lampert et al., 2019). 해당 방법 또한 추 후 연구에서 고려해볼 수 있을 것이다.

몇 가지 한계점에도 불구하고, 본 연구는 여러 가지 의의를 지닌다. 한국 표본을 대상 으로 고객응대상황에서 정서노동자들이 고객 에 가지는 태도와 관련된 분리된 관심이라는 개념을 소개했으며, 직무탈진을 준거변수로 활용해 타당도를 확인하였다. 척도의 내적일 치도가 낮았음에도 불구하고 직무열의와 유 의한 결과가 나왔다는 것은 그만큼 분리와 관심의 일치와 불일치가 정서노동자의 정신 건강 및 직무태도에 중요한 영향을 미칠 수 있는 요소임을 보여준다. 따라서 분리된 관심 은 의료계뿐만 아니라 산업 및 조직심리학 분야에서도 주목받을 만한 개념으로, 더욱 많 은 연구들을 통해 분리된 관심에 대한 이해 를 높여야 한다. 본 연구를 통해 고객응대 종 사자의 웰빙 및 고객응대의 질과 관련 있는 분리된 관심에 대한 국내 연구를 촉진하길 기대한다.

\section{참고문헌}

Allen, J. A., Diefendorff, J. M., \& Ma, Y. (2014). 
Differences in emotional labor across cultures: A comparison of Chinese and US service workers. Journal of Business and Psychology, 291), 21-35.

Bakker, A. B. (2011). An evidence-based model of work engagement. Current Directions in Psychological Science, 20(4), 265-269. https://doi.org/10.1177/0963721411414534

Bakker, A. B., Demerouti, E. (2007). The job demands-resources model: State of the art. Journal of Managerial Psychology, 22(3), 309-328. https://doi.org/10.1108/02683940710733115

Bakker, A. B., Schaufeli, W. B., Leiter, M. P., \& Taris, T. W. (2008). Work engagement: An emerging concept in occupational health psychology. Work \& Stress, 22(3), 187-200. https://doi.org/10.1080/02678370802393649

Becker, T. E., Atinc, G., Breaugh, J. A., Carlson, K. D., Edwards, J. R., \& Spector, P. E. (2016). Statistical control in correlational studies: 10 essential recommendations for organizational researchers. Journal of Organizational Behavior, 37(2), 157-167. https://doi.org/10.1002/job.2053

Bond, F. W., \& Bunce, D. (2001). Job control mediates change in a work reorganization intervention for stress reduction. Journal of Occupational Health Psychology, Q4), 290-302. https://doi.org/10.1037/1076-8998.6.4.290

Cadge, W., \& Hammonds, C. (2012). Reconsidering detached concern: The case of intensive-care nurses. Perspectives in Biology and Medicine, 55(2), 266-282.

https://doi.org/10.1353/pbm.2012.0021

Chen, C. F., \& Kao, Y. L. (2012). Moderating effects of work engagement and job tenure on burnout - Performance among flight attendants. Journal of Air Transport Management, 25, 61-63. https://doi.org/10.1016/j.jairtraman.2012.08.009

Christian, M. S., \& Slaughter, J. E. (2007, August). Work engagement: A meta-analytic review and directions for research in an emerging area. Paper presented at the sixty-seventh annual meeting of the Academy of Management, Philadelphia, PA.

Coulehan, J. (2012). Suffering, hope, and healing. In R. J. Moore (Ed.), Handbook of pain and palliative care: Biobehavioral approaches for the life course (pp. 717-731). Springer.

Coombs, R. H., \& Goldman, L, J. (1973). Maintenance and discontinuity of coping mechanisms in an intensive care unit. Social Problems, 20(3), $342-355$. https://doi.org/10.2307/799598

Davis, M. H. (1983). Measuring individual differences in empathy: Evidence for a multidimensional approach. Journal of Personality and Social Psychology, 44(1), $113-126$. http://dx.doi.org/10.1037/0022-3514.44.1.113

DeVellis, R. F. (1991). Scale development: Theory and applications. Sage Publications, Inc.

Dickinson, G. E., Lancaster, C, J., Winfield, I. C., Reece, E, F., Colthorpe, C. A. (1997). Detached concern and death anxiety of first-year medical students: Before and after the gross anatomy course. Clinical Anatomy, 10(3), 201-207. https://https://doi.org/10.1002/(SICI)1098-2353 (1997)10:3<201::AID-CA5>3.0.CO;2-W

Dorman, J. (2003). Testing a model for teacher 
burnout. Australian Journal of Educational \& Developmental Psychology, 3(1), 35-47. https://bit.ly/2YVH8XF

Dougherty, T. W., \& Cordes, C. L. (1993). A review and an integration of research on job burnout. The Academy of Management Review, 18(4), 621-656

Druce, M, Johnson, M. H. (1994). Human dissection and attitudes of preclinical students to death and bereavement. Clinical Anatomy, 7(1), $42-49$. https://doi.org/10.1002/ca.980070108

Dutton, J. E., Workman, K. M., \& Hardin, A. E. (2014). Compassion at work. Annual Review of Organizational Psychology and Organizational Behavior, 1(1), 277 - 304.

https://10.1146/annurev-orgpsych-031413-091221

Elfenbein, H. A. (2007). Emotion in organizations: A review and theoretical integration. Academy of Management Annals, 1(1), 371-457.

Elsass, P. M., \& Veiga, J. F. (1997). Job control and job strain: A test of three models. Journal of Occupational Health Psychology, 2(3), $195-211$.

https://doi.org/10.1037/1076-8998.2.3.195

Figley, C. R. (2002). Compassion fatigue: Psychotherapists' chronic lack of self care. Journal of Clinical Psychology, 58(11), 14331441. https://doi.org/10.1002/jclp.10090

Fluttert, F. A., Van Meijel, B., Nijman, H., Bjørkly, S., \& Grypdonck, M. (2010a). Preventing aggressive incidents and seclusions in forensic care by means of the 'Early Recognition Method'. Journal of Clinical Nursing, 19(11-12), 1529-1537. https://doi.org/10.1111/j.1365-2702.2009.02986.x Fluttert, F. A., Van Meijel, B., Nijman, H., Bjørkly, S., \& Grypdonck, M. (2010b). Detached concern of forensic mental health nurses in therapeutic relationships with patients: The application of the early recognition method related to detached concern. Archives of Psychiatric Nursing, 24(4), 266-274. https://doi.org/10.1016/j.apnu.2009.09.002

Ganster, D. C., \& Fusilier, M. R. (1989). Control in the workplace. International Review of Industrial and Organizational Psychology, 4, 235-280.

Goswami, A., Park, H. I., \& Beehr, T. A. (2020). Does the congruence between leaders' implicit followership theories and their perceptions of actual followers matter? Journal of Business and Psychology, 35, 519-538. https://doi.org/10.1007/s10869-019-09638-7

Grandey, A. A. (2000). Emotion regulation in the workplace: A new way to conceptualize emotional labor. Journal of Occupational Health Psychology, 5(1), 95-110. https://doi.org/10.1037//1076-8998.5.1.95

Greer, J. G., \& Greer, B. B. (1992). Stopping burnout before it starts: Prevention measures at the preservice level. Teacher Education and Special Education, 15(3), 168-174.. https://doi.org/10.1177/088840649201500303

Gross, J. J. (1998). Antecedent-and response-focused emotion regulation: Divergent consequences for experience, expression, and physiology. Journal of Personality and Social Psychology, 74(1), 224. Gross, J. J. (2015). Emotion regulation: Current 
status and future prospects. Psychological Inquiry, 26(1), 1-26.

https://doi.org/10.1080/1047840X.2014.940781

Gustavson, N. (1988). The effect of human dissection on first-year students and implications for the doctor-patient relationship. Journal of Medical Education, 63(1), $62-64$. https://doi.org/110.1097/00001888-19880100000011

Hakanen, J. J., Bakker, A. B., \& Demerouti, E. (2005). How dentists cope with their job demands and stay engaged: The moderating role of job resources. European Journal of Oral Sciences, 113(6), $479-487$.

http://dx.doi.org/10.1111/j.1600-0722.2005.002 50. $\mathrm{x}$

Halbesleben, J. R., \& Demerouti, E. (2005). The construct validity of an alternative measure of burnout: Investigating the English translation of the Oldenburg Burnout Inventory. Work \& Stress, 19(3), 208-220.

Halpern, J. (2001). From detached concern to empathy. Humanizing medical practice. University Press. http://dx.doi.org/10.1093/acprof:osobl/97801951 11194.001 .0001

Harter, J. K., Schmidt, F. L., \& Hayes, T. L. (2002). Business-unit-level relationship between employee satisfaction, employee engagement, and business outcomes: a meta-analysis. Journal of Applied Psychology, 872), 268-279. http://dx.doi.org/10.1037/0021-9010.87.2.268

Häusser, J. A., Mojzisch, A., Niesel, M., \& Schulz-Hardt, S. (2010). Ten years on: A review of recent research on the job demand - control (-support) model and psychological well-being. Work and Stress, 24(1), 1-35. http://dx.doi.org/10.1080/02678371003683747

Havens, D. S., Warshawsky, N. E., \& Vasey, J. (2013). RN work engagement in generational cohorts: The view from rural US hospitals. Journal of Nursing Management, 21(7), 927-940. http://dx.doi.org/10.1111/jonm.12171

Hochschild, A. R. (2012). The managed heart: Commercialization of human feeling. University of California Press.

Hofstede, G. (2011). Dimensionalizing cultures: The Hofstede model in context. Online Readings in Psychology and Culture, 2(1), 2307-0919.

Hojat, M., Gonnella, J. S., Nasca, T. J., Mangione, S., Vergare, M., \& Magee, M. (2002). Physician empathy: Definition, components, measurement, and relationship to gender and specialty. The American Journal of Psychiatry, 1599), 1563-1569. https://doi.org/10.1176/appi.ajp.159.9.1563

Hong, S. H. (2000). The criteria for selecting appropriate fit indices in structural equation modeling and their rationales. Korean Journal of Clinical Psychology, 19(1), 161-177.

Hülsheger, U. R., \& Schewe, A. F. (2011). On the costs and benefits of emotional labor: A meta-analysis of three decades of research. Journal of Occupational Health Psychology, 16(3), 361-389. http://dx.doi.org/10.1037/a0022876

Jamal, M. (2005). Burnout among Canadian and Chinese employees: A cross-cultural study. European Management Review, 2(3), 224-230. https://doi.org/10.1057/palgrave.emr.1500038

Jang, J. S., \& Park, H. I. (2018). The interaction 
between leadership and personal power in work engagement. Korean Journal of Industrial and Organizational Psychology, 31(1), 59-80.

Jensen, N. (1994). The empathic physician. Archives of Internal Medicine, 154(1), 106-106. https://doi:10.1001/archinte.1994.004200101420 17

Jöreskog, K. G., \& Sörbom, D. (2017). LISREL 9.30 for Windows [Computer software]. Scientific Software International, Inc.

Kammeyer-Mueller, J. D., Rubenstein, A. L., Long, D. M., Odio, M. A., Buckman, B. R., Zhang,Y., \& Halvorsen-Ganepola, M. D. (2013). A meta-analytic structural model of dispositional affectivity and emotional labor. Personnel Psychology, 66, 47-90. https://doi.org/10.1111/peps.12009

Karasek, R. A., Jr. (1979). Job demands, job decision latitude, and mental strain: Implications for job redesign. Administrative Science Quarterly, 24(2), 285 - 308.

http://dx.doi.org/10.2307/2392498

Kim, Y. O. (2015). Development and Validation of the Korean Scale of Role Stressors [Master's Thesis]. Chonnam University.

Kim, Y. O., \& Park, H. I. (2014). A metaanalytic study of the relationship between role stressor and burnout. Journal of Modern Social Science, 18, 61-71.

Kline, R. B. (2016). Principles and practice of structural equation modeling (4th ed.). Guilford Press.

Korean Ministry of Employment and Labor. (2017). Handbook of health protection in emotional labor workers. Author.
Kristof-Brown, A. L., \& Stevens, C. K. (2001) Goal congruence in project teams: Does the fit between members' personal mastery and performance goals matter? Journal of Applied Psychology, 86(6), 1083 - 1095. http://dx.doi.org/10.1037/0021-9010.86.6.1083

Lampert, B., \& Glaser, J. (2018). Detached concern in client interaction and burnout. International Journal of Stress Management, 25(2), 129 - 143. https://doi.org/10.1037/str0000053

Lampert, B., Unterrainer, C., \& Seubert, C. T. (2019). Exhausted through client interaction: Detached concern profiles as an emotional resource over time? PloS ONE, 14(5). https://doi.org/10.1371/journal.pone.0216031

Luong, G., Arredondo, C. M., \& Charles, S. T (2020). Cultural differences in coping with interpersonal tensions lead to divergent shorter-and longer-term affective consequences. Cognition and Emotion, 34(7), 1499-1508. https://doi.org/10.1080/02699931.2020.1752153

Mannon, J. M. (1981). Aiming for "detached concern": How EMTs and paramedics cope. Emergency Medical Services, 103), 6-20.

Maslach, C., \& Leiter, M. P. (2017). New insights into burnout and health care: Strategies for improving civility and alleviating burnout. Medical Teacher, 392), 160-163.

Maslach, C., Schaufeli, W. B., \& Leiter, M. P. (2001). Job burnout. Annual Review of Psychology, 52, 397-422. https://doi.org/10.1146/annurev.psych.52.1.397

Mauno, S., Kinnunen, U., \& Ruokolainen, M. (2007). Job demands and resources as antecedents of work engagement: A 
longitudinal study. Journal of Vocational Behavior, 701), 149-171. https://doi.org/10.1016/j.jvb.2006.09.002

Park, H. I. (2019). Sequential mediation from emotional labor to job burnout: Contrast between surface acting and deep acting. Korean Journal of Psychology: General, 38(4), 599-623.

http://dx.doi.org/10.22257/kjp.2019.12.38.4.599

Park, H. I., Jacob, A. C., Wagner, S. H., \& Baiden, M. (2014). Job control and burnout: A meta-analytic test of the conservation of resources model. Applied Psychology: An International Review, 63(4), 607-642. https://doi.org/10.1111/apps.12008

Park, H. I., Jang, J., \& Nam, J. S. (2021). Physical activity buffers the effects of work-family conflict on work engagement through mastery recovery experience. Current Psychology. Advance online publication. https://doi.org/10.1007/s12144-021-01463-7

Park, H. I., Lee, S.-M., \& Kim, Y. N. (2021). Psychological reattachment to work: Its nomological network and role in the relationship between role ambiguity and work engagement. Journal of Social Science, 32(2), 43-67.

http://dx.doi.org/10.16881/jss.2021.04.32.2.43

Park, H. I., Park, Y. A., Kim, M., \& Hur, T. (2011). A validation study of a Korean version of the recovery experience questionnaire. Korean Journal of Industrial and Organizational Psychology, 24(3), 523-552.

Peiró, J. M., González-Romá, V., Tordera, N., \& Mañas, M. A. (2001). Does role stress predict burnout over time among health care professionals? [Special issue] Psychology \& Health.: Burnout and Health, 16(5), $511-525$. https://doi.org/10.1080/08870440108405524

Peretz, H., \& Fried, Y. (2012). National cultures, performance appraisal practices, and organizational absenteeism and turnover: A study across 21 countries. Journal of Applied Psychology, 97(2), 448-459.

https://doi.org/10.1037/a0026011

Schaufeli, W. B. (2003). Past performance and future perspectives of burnout research. $S A$ Journal of Industrial Psychology, 294), 1-15. https://doi.org/10.4102/sajip.v29i4.127

Schaufeli, W. B. (2012). Work Engagement. What Do We Know and Where Do We Go? Romanian Journal of Applied Psychology, 14(1), 3-10.

Schaufeli, W. B., \& Bakker, A. B. (2004). Job demands, job resources, and their relationship with burnout and engagement: A multisample study. Journal of Organizational Behavior, 25(3), 293-315. https://doi.org/10.1002/job.248

Schaufeli, W. B., Salanova, M., González-Romá, V., \& Bakker, A. B. (2002). The measurement of engagement and burnout: A two sample confirmatory factor analytic approach. Journal of Happiness Studies, 3(1), 71-92. https://doi.org/10.1023/A:1015630930326

Schmidt, F. L., \& Hunter, J. E. (1996). Measurement error in psychological research: Lessons from 26 research scenarios. Psychological Methods, 1(2), 199-223.

Schmidt, F. L., \& Hunter, J. E. (2015). Methods of meta-analysis Correcting error and bias in research 
findings ( $3^{\text {rd }}$ ed.). Sage Publication, Inc. https://dx.doi.org/10.4135/9781483398105

Shanock, L. R., Baran, B. E., Gentry, W. A., Pattison, S. C., \& Heggestad, E. D. (2010). Polynomial regression with response surface analysis: A powerful approach for examining moderation and overcoming limitations of difference scores. Journal of Business and Psychology, 25(4), 543-554.

https://doi.org/10.1007/s10869-010-9183-4

Shanock, L. R., Baran, B. E., Gentry, W. A., Pattison, S. C., \& Heggestad, E. D. (2014). Erratum to: Polynomial regression with response surface analysis: A powerful approach for examining moderation and overcoming limitations of difference scores. Journal of Business and Psychology, 29(1), 161. https://doi.org/10.1007/s10869-013-9317-6

Shin, K. H. (2003). The Maslach burnout inventory-general survey (MBI-GS): An application in South Korea. Korean Journal of Industrial and Organizational Psychology, 16(3), $1-17$.

Sonnentag, S., \& Bayer, U. V. (2005). Switching off mentally: Predictors and consequences of psychological detachment from work during off-job time. Journal of Occupational Health Psychology, 10(4), $393-414$.

http://dx.doi.org/10.1037/1076-8998.10.4.393

Spector, P. E., Allen, T. D., Poelmans, S. A., Lapierre, L. M., Cooper, C. L., O'Driscoll, M., Sanchez, J. I., Abarca, N., Alexandrova, M., Beham, B., Brough, P., Ferreriro, P., Fraile, G., Lu, C.-Q., Lu, L., Moreno-Velázquez, I., Pagon, M., Pitariu, H., Salamatov, V. ...
Widerszal-Bazyl， M. (2007). Cross national differences in relationships of work demands, job satisfaction, and turnover intentions with work - family conflict. Personnel Psychology, 60(4), 805-835.

https://doi.org/10.1111/j.1744-6570.2007.00092.x

Taber, K. S. (2018). The use of Cronbach's alpha when developing and reporting research instruments in science education. Research in Science Education, 48(6), 1273-1296. https://doi.org/10.1007/s11165-016-9602-2

Tims, M., \& Bakker, A. B. (2010). Job crafting: Towards a new model of individual job redesign. SA Journal of Industrial Psychology, $36(2), 1-9$. https://doi.org/10.4102/sajip.v36i2.841

Van der Doef, M., \& Maes, S. (1999). The job demand-control (-support) model and psychological well-being: A review of 20 years of empirical research. Work \& Stress, 13(2), 87-114.

http://dx.doi.org/10.1080/026783799296084

Van Yperen, N. W., \& Hagedoorn, M. (2003). Do high job demands increase intrinsic motivation or fatigue or both? The role of job control and job social support. Academy of Management Journal, 46(3), 339-348. https://doi.org/10.2307/30040627

Varca, P. E. (2009). Emotional empathy and front line employees: Does it make sense to care about the customer? Journal of Services Marketing, 23(1). 51-56. https://doi.org/10.1108/08876040910933093

Wieseke, J., Geigenmüller, A., \& Kraus, F. (2012). On the role of empathy in customer-employee 
남지선 · 박형인 / 분리된 관심의 척도 타당화 및 직무열의와의 관계 연구

interactions. Journal of Service Research, 15(3),

316-331.

https://doi.org/10.1177/1094670512439743
투고일자 : 2021. 03. 10 수정일자 : 2021. 06. 04 확정일자 : 2021. 10. 13 . 


\title{
Detached Concern: Testing of the Scale Validity and the Relationship with Work Engagement
}

\author{
Ji Sun Nam \\ Hyung In Park \\ Department of Psychology, Sungkyunkwan University
}

\begin{abstract}
This study attempted to apply the concept of detached concern, an attitude that service workers may have towards customers, to Korean samples. In Study 1, the original detached concern scale was translated into Korean and then back-translated for comparison and refinement. The Korean detached concern scale was then validated with a sample of 143 full-time, overage Korean workers using three facets of burnout as the criteria. The results of confirmatory factor analyses indicated that detachment and concern were two independent facets. Also, the response surface graph showed that professional inefficacy significantly decreased when detachment and concern matched at high levels rather than at low levels. In Study 2, we examined whether detached concern would predict the three facets of work engagement after a month with 374 Korean customer service workers using the scale validated in Study 1. We also hypothesized that job control would weaken the relationships. All variables were measured twice with a one-month interval. Polynomial regressions revealed that detachment and concern measured at Time 1 jointly had significant effects on all facets of work engagement measured at Time 2. Also, the moderating effects of job control were observed but different for all three facets. These results suggest that detached concern may play an important role in the psychological well-being of emotional labor workers. Based on these findings, academic and practical implications were discussed along with suggestions for future research.
\end{abstract}

Key words : detached concern, scale validation, burnout, work engagement, job control, response surface graph 